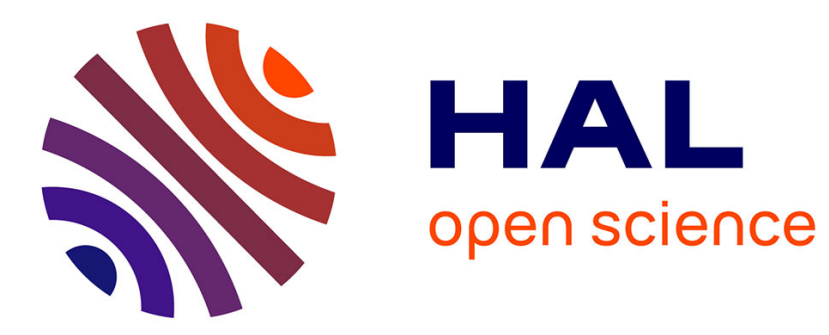

\title{
Multi-scale depositional successions in tectonic settings
}

Liviu Matenco, Bilal U Haq

\section{To cite this version:}

Liviu Matenco, Bilal U Haq. Multi-scale depositional successions in tectonic settings. Earth-Science Reviews, 2020, 200, pp.102991. 10.1016/j.earscirev.2019.102991 . hal-02553400

\section{HAL Id: hal-02553400 \\ https: / hal.sorbonne-universite.fr/hal-02553400}

Submitted on 24 Apr 2020

HAL is a multi-disciplinary open access archive for the deposit and dissemination of scientific research documents, whether they are published or not. The documents may come from teaching and research institutions in France or abroad, or from public or private research centers.
L'archive ouverte pluridisciplinaire HAL, est destinée au dépôt et à la diffusion de documents scientifiques de niveau recherche, publiés ou non, émanant des établissements d'enseignement et de recherche français ou étrangers, des laboratoires publics ou privés. 


\title{
Multi-scale depositional successions in tectonic settings
}

\author{
Liviu C. Matenco ${ }^{\mathrm{a}, *}$, Bilal U. Haq ${ }^{\mathrm{a}, \mathrm{b}, \mathrm{c}}$ \\ ${ }^{a}$ Utrecht University, Department of Earth Sciences, Utrecht, The Netherlands \\ ${ }^{\mathrm{b}}$ Sorbonne University, Institute of Earth Sciences, Paris, France \\ ${ }^{\mathrm{c}}$ Smithsonian Institution, Department of Paleobiology, Washington, DC, USA
}

\section{A R T I C L E I N F O}

\section{Keywords:}

Tectonic successions

Sedimentary basins

Basinward shifting facies tracts

Sourceward shifting facies tracts

Extensional basins

Contractional basins

Strike-slip basins

\begin{abstract}
A B S T R A C T
Observations in sedimentary basins affected by deformation show that the fault-induced depositional accommodation, at various spatial and temporal scales, is closely linked to basin kinematics. The tectonically-driven sediment infill displays the history of deepening and shoaling facies that are controlled by the activation of faults and changes in their offset rates. Simply stated, this results in shifting sedimentary facies towards the source area or towards the basin centre in response to increasing or decreasing depositional space. We propose a firstprinciple conceptual model for tectonic successions, controlled by the balance between the rates of creation of depositional space and sediment supply. These sediment bodies are bounded by succession boundaries and comprise sourceward or basinward shifting facies tracts that are separated at a point of reversal. Due to the relatively steep slopes associated with the evolution of faults, changes in sediment supply rates and mass-wasting are common in these systems and may complicate the normal rhythm of the shifting facies tracts. Once tectonic quiescence is achieved, and if the basin is connected to the open ocean, eurybatic or eustatic base level changes may take over and play a greater role in sedimentary rhythm and cyclicity. We illustrate the efficacy of the new concept with a review of examples from extensional, contractional and strike-slip basins. We show that the basic tectonic succession model is applicable at all temporal and spatial scales and whether the tectonics cause subsidence or uplift, and in all types of tectonic settings that determine the evolution of sedimentary basins.
\end{abstract}

\section{Introduction}

Large to small scale Earth movements, together with erosion, control most aspects of global surficial morphology (e.g., Oncken et al., 2006; Cloetingh et al., 2007; von Hagke et al., 2014, among others). Among prominent surficial features are sedimentary basins, formed in the Earth's upper crust, often initiated by deep- or shallow-seated tectonics that create new depositional (accommodation) space for sediments (Fig. 1, e.g., Cloetingh et al., 2015; Noda, 2016; Sato et al., 2017; Ballato et al., 2019). When connected to the open ocean, accommodation is also modulated by sea-level fluctuations, especially in the post-diastrophic phases of the basinal evolution (e.g., Vail et al., 1977a; van Wagoner et al., 1990; Haq, 2014). New space for deposition can also be generated through thermal cooling and subsidence of the lithosphere (e.g., Turcotte and Ahern, 1977; Faccenna et al., 2013; Burov and Gerya, 2014), as well as an expression of the long wavelength thermo-elastic flexure that has been broadly labelled as dynamic topography (e.g., Gurnis, 1993; Bertelloni and Gurnis, 1997; Flament et al., 2013). Surface topography, which results from the lithospheric memory retained at several temporal and spatial scales, plays an important role in the assembly and the resultant profile of the stratigraphic architecture (e.g., Cloetingh and Haq, 2015 and references therein).

With this cognizance, it seemed appropriate to us to first re-examine how tectonics (vertical and horizontal displacements) generate depositional accommodation on more local or regional scales and identify the common elements of tectonic successions that occupy sedimentary basins. The efficacy of the conceptual model of tectonic successions thus developed can then be tested with a careful review of depositional patterns in various types of basins with examples from various tectonic settings (Fig. 1). Our objective here has been to present a working model that is based on first principles of the interaction between accommodation (depositional space) and sediment supply (availability of sediments to fill the basin by advective, diffusive, biogenic and masswasting processes) in tectonic settings. Such basic-tenets practice has already been advocated for passive margin shallow-water sequences, such as that by Neal et al. (2016) and their "accommodation succession $(\delta \mathrm{A} / \delta \mathrm{S})$ " approach, which has considerable appeal in simplifying the sequence-stratigraphic idiom. This is particularly true for tectonic deposits, where we use the term "successions" to differentiate them from

\footnotetext{
* Corresponding author.

E-mail address: liviu.matenco@uu.nl (L.C. Matenco).
} 


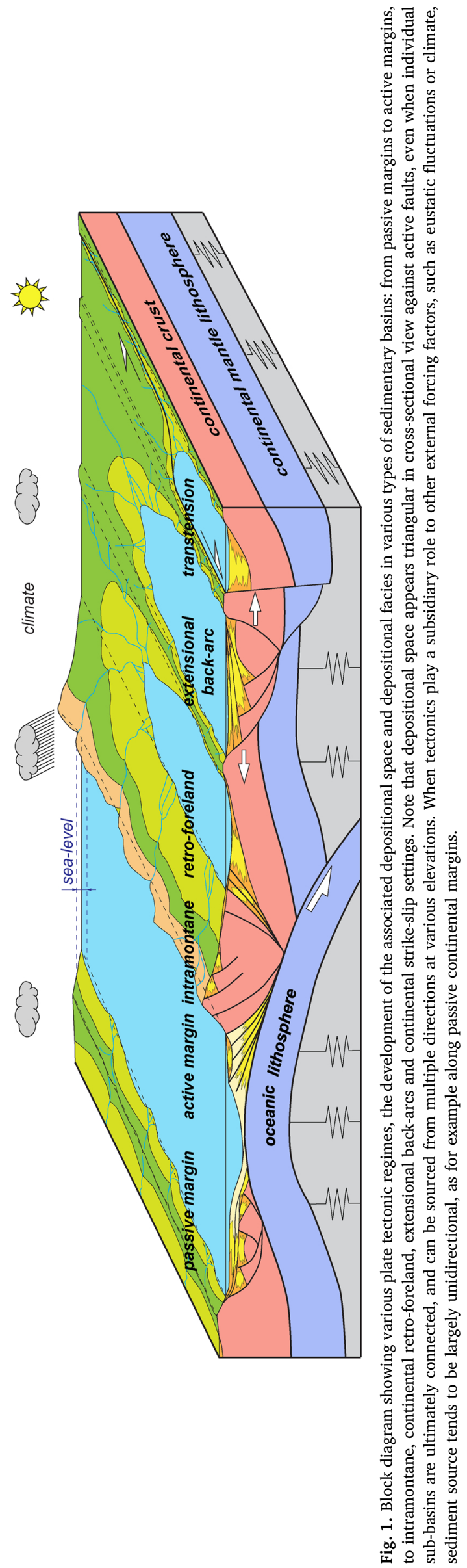

the terminology of sequence stratigraphy.

The infill history of a sedimentary basin primarily records the interaction between rate of creation (or elimination) of depositional (accommodation) space ( $\delta \mathrm{AS})$ and the rate of sediment supply ( $\delta \mathrm{SS})$ (e.g., Jervey, 1988; Schlager, 1993). The latter is primarily controlled by climate, erosional processes, distance to the source area, size of the drainage basin and the presence of intermediate basins that might trap sediment flux (e.g., Matenco et al., 2016). On relatively stable passive margins, where the source of sediment supply is largely unidirectional, this interplay results in distinct facies and stratal architecture (e.g., Mitchum et al., 1977; Posamentier and Allen, 1999). These stratal associations can be characterized as building out (progradational, i.e., $\delta \mathrm{AS} / \delta \mathrm{SS}=<1$ ), building up (aggradational, i.e., $\delta \mathrm{AS} / \delta \mathrm{SS}=1$ ) or back-stepping (retrogradational, i.e., $\delta A S / \delta S S=>1$ ) successions (e.g., van Wagoner et al., 1990) that are often interpreted as the movement of shoreline in response to eurybatic (relative sea-level) changes, which remains the basis of sequence-stratigraphic analysis (e.g., Vail et al., 1977b; Haq et al., 1987; Hardenbol et al., 1999; Posamentier and Allen, 1999; Catuneanu et al., 2009; Pomar and Haq, 2016). This relatively simple relationship breaks down if the source of sediment supply is multidirectional (e.g., in interior basins or lakes), especially if sediments from different source areas have a tendency to interfinger on the basin floor (e.g., Haughton, 2001; Leever et al., 2006; Fongngern et al., 2016; Balázs et al., 2018).

Descriptions of tectonics-related basin fills are often couched in eustatic (or eurybatic) terms, and while the background influence of climate or sea-level change is undeniable, once a basin connects to the ocean it is quite unnecessary to use the terminology of sequence stratigraphy or ocean's transgressive-regressive cyclicity (e.g., Hardenbol et al., 1999; Embry, 2002; Catuneanu, 2019 and references therein) to characterize tectonic successions at various scales. Such successions are largely affected by the dynamics of Earth movements and often start off in non-marine settings (e.g., Dickinson, 1974; Einsele, 2000). This is the case in most basins generated by fault tectonics, where the use of geometric retrogradation - progradation terminology (implying shoreline movements associated with transgression - regression) is untenable, because the use of such terms does not describe fault-related vertical movements, but rather imply the variability of sediment influx. Furthermore, the sequence-stratigraphic terminology was developed on stable continental margins and was tied to the concepts of onlap and offlap and resulting stratal patterns. Tectonic successions, on the other hand, can develop in any setting, which may include intra-montane and interior basins, far from the marine domain, as well as in marine basins far from the influence of coastal areas. Thus, the use the sequencestratigraphic terminology to describe tectonic successions can be misleading. These shortcomings have prevented the development of a generic terminology that can be employed in fault-related successions at all scales and types. Another important difference in conceptualizing tectonic successions is the fact the while climate/sea-level driven stratal architectures reflect the interaction between accommodation and sediment supply, tectonic successions have to analysed also in terms of changes in topography (elevation) and bathymetry (depth) associated with vertical movements.

\section{Tectonic successions and their facies tracts}

On a local or regional scale Earth movements are most commonly expressed as faults in the upper crust, caused by rock failures, that simultaneously create room for sediment deposition on their subsiding sides (the local sink) and erosion that generates sediment supply on their uplifted sides (the local source) (e.g., Matenco and Andriessen, 2013; Morley, 2014; Hawie et al., 2017; Horton, 2018). The fault-created depocenters tend to be triangular in cross-sectional profile (Fig. 1), often with steep slopes that accumulate wedge-shaped sediment fills sourced from one or more areas of sediment supply. Mass wasting of existing sediments, such as slides, slumps and debris flows are the most 
common features that rest on or at the foot of such steep slopes (e.g., Galloway, 1986; Scholz et al., 1993; Dondurur et al., 2013), often with turbiditic extensions onto the basin floors.

Most sedimentary basins have an early tectonic component, even if later they evolve into stable "passive" basins or margins (e.g., Heller et al., 1988; Ziegler and Cloetingh, 2004). Tectonically-generated, faultbounded basins come in many guises, but they can be classed into three main categories, i.e., extensional (such as rift or intramontane) basins, contractional (foredeep or wedge-top) basins, and strike-slip basins (Fig. 1). The sediment-fill successions in all of these basin types have some elements in common: 1) basal unconformity associated with the onset of faulting; 2) common occurrence of mass-wasting deposits, especially in the early phases; 3 ) early stages can also show a transition from continental (non-marine) to marine facies; 4) as the basin fills, facies associations vary in response to changes in $\delta \mathrm{AS} / \delta \mathrm{SS}$ ratio, expressed as sourceward and basinward migrating facies tracts.

Tectonics create new depositional space by fault movement and subsidence, including sediment compaction, independently of sea-level variations. Therefore, for tectonic successions we prefer a terminology that describes the observable stratal/facies patterns rather than underlying controlling factors (often prone to multiple causes and interpretations). Our preferred terminology is explicitly based on the dynamic interaction of changes in the rate of creation of depositional accommodation with sediment supply that would be applicable to all fault-bounded basin types. Thus, to avoid the ambiguity of using stratalstacking terminology of seismic and sequence stratigraphy that implies regressive/transgressive sea-level control (i.e., expressed as progradation and retrogradation), we advocate the use of terms that simply imply the distribution of facies associations in response to each phase of tectonic movement.

We conceptualize lower as well as higher order tectonic successions (TS) by the balance between the rate of creation of depositional (accommodation) space ( $\delta \mathrm{AS})$ and the rate of sediment supply ( $\delta \mathrm{SS}$ ) (Fig. 2). These tectonic successions $\left(\mathrm{TS}^{\mathrm{i}}\right.$ and $\mathrm{TS}^{\mathrm{i}+1}$, respectively) are separated by succession boundaries $\left(\mathrm{SB}^{\mathrm{i}}\right.$ and $\mathrm{SB}^{\mathrm{i}+1}$ ). The succession boundary at base of the lower order tectonic succession is represented by a diachronous fault-bounded unconformity, whereas the one at the top may be an erosional boundary. The top is also time transgressive and marks the transition from a tectonically active period to post-tectonic relative quiescence, which is the equivalent of, for example, the so-called "breakup unconformity" in extensional systems. The building blocks of the lower-order $\mathrm{TS}^{\mathrm{i}}$ are higher-order sediment-fill events (i.e. higher order $\mathrm{TS}^{\mathrm{i}+1}$ tectonic successions), such as individual pulses of fault movement.

"Facies tract" is a term that has been previously used to describe the relatively contemporaneous facies associations (e.g., nearshore or offshore facies), and when a sea-level control is implied, either characterized as "transgressive" and "regressive" facies tracts (e.g., Brown and Fisher, 1977; Shanley and McCabe, 1991; Sinclair, 1993; Burns et al., 1997), or physiographically, as "slope" and "basinal" facies tracts (Slatt et al., 2000). We adopt the term "facies tracts" by defining two distinct types of shift patterns in facies associations in tectonic successions (Fig. 2), without reference to transgressive or regressive shoreline movements. We term the first sourceward-shifting facies tracts (SFT) when shallower water facies shift toward the source of sediment supply due to higher rate of creation of depositional space compared to the rate of sediment supply (i.e., $\delta A S / \delta S S=>1$ ). Similarly, the second basinward-shifting facies tracts (BFT) is defined when shallower-water facies in each successively younger facies association migrate basinward in response to a lower rate of creation of depositional space compared to the rate of sediment supply (i.e., $\delta \mathrm{AS} / \delta \mathrm{SS}=<1$ ). The sourcewardshifting facies tract is separated from the overlying basinward-shifting facies tract by a point of reversal (POR), which is the position when the rate of sediment supply exceeds the rate of creation of depositional space. Although we term the position of change in the shift patterns as a "point "of reversal, in practice this is a boundary that can be gleaned as a diachronous surface along its total extent. In young tectonic basins such alternations of SFTs and BFTs may occur in multiple directions moving away from the depositional centre on the basin floor toward basin margins (depending of the number of sources of sediment supply).

Our conceptual model of tectonic facies tracts can be applied at both lower and higher orders of tectonic movements and basin development. Although the facies tracts are shown to be similar in dimensions in our conceptual model (Fig. 2), in reality they can vary appreciably in thickness and extent. In addition, the introduction of slope-failure related mass-wasting deposits (that are very common features in tectonic successions and can be found in all facies tracts) may also complicate the overall stratal architecture.

\section{A review of tectonic basins and their sedimentary successions}

In this section we review the sedimentary depositional patterns in most common types of tectonic basins in the light of our new tectonic successions concept that illustrates the application of this simple, firstprinciples' model and shows how it is independent of the type of deformation and can be applied in different tectonically-driven depositional settings.

\subsection{Extensional basins}

Extensional (rift) basins result from lithospheric stretching by divergent tectonic movements, often reactivating older suture zones, and generally start to develop in either intra-cratonic areas, such as the East African Rift, or in back-arc regions, such as the Mediterranean and the Southeast Asian basin systems, where extension is driven by the rollback of slabs during oceanic or continental subduction (e.g., Chorowicz, 2005; Faccenna et al., 2014; Pubellier and Morley, 2014; Heron et al., 2016 and references therein). In such systems, the organisation of normal faults may result in the formation of quasi-symmetrical halfgrabens with changing kinematics along their strike, where the localisation of deformation is often controlled by the inherited rheology of continental plates (e.g., van Wijk et al., 2008; Corti, 2009). Extension may also be associated with tens of kilometres of exhumation in the footwall of asymmetric detachments or low-angle normal faults, where kilometres-size (half-) grabens become gradually tilted by the continuation of deformation (e.g., Angelier and Colletta, 1983; Buck, 1991; Tirel et al., 2008; Buck, 2015). Depositional space in such basins is created by the subsidence of hanging-walls during successive events of normal faulting or may be cancelled by the relative uplift of footwalls associated with flexural effects or active rifting mechanics (e.g., Ziegler and Cloetingh, 2004). Space is also commonly created by the overlying (or laterally displaced) sagging, brought on by thermal cooling of stretched lithosphere, sometimes assisted by dynamic asthenospheric effects, conditioned by the presence of inherited rheological weakness zones, or by extreme lithospheric thinning effects driven by the exhumation of continental mantle lithosphere (e.g., McKenzie, 1978; Wernicke, 1985; Manatschal et al., 2015; Balázs et al., 2017a; Naliboff et al., 2017).

Detailed documentation and models of sedimentation associated with the moments of slip along normal faults, which are coeval with the hanging-wall subsidence creating depositional space and footwall uplift enhancing source areas and mass-wasting processes, is widely available from outcrop studies carried out in small to medium size extensional basins in either clastic, carbonate or mixed depositional settings (e.g., Bosence, 2005; Leppard and Gawthorpe, 2006; Hinsken et al., 2007; Cross and Bosence, 2008; Strachan et al., 2013; Henstra et al., 2016; Alves and Cupkovic, 2018; Andrić et al., 2018, among many others). In contrast to such detailed documentation, only few genetic sedimentation models are available for the entire or parts of extensional basins (Fig. 3) based on empirical observations and interpretation of reflection seismic profiles, well-logs and outcrops. Based on lithofacies distribution, these models demonstrate that the system works toward achieving 


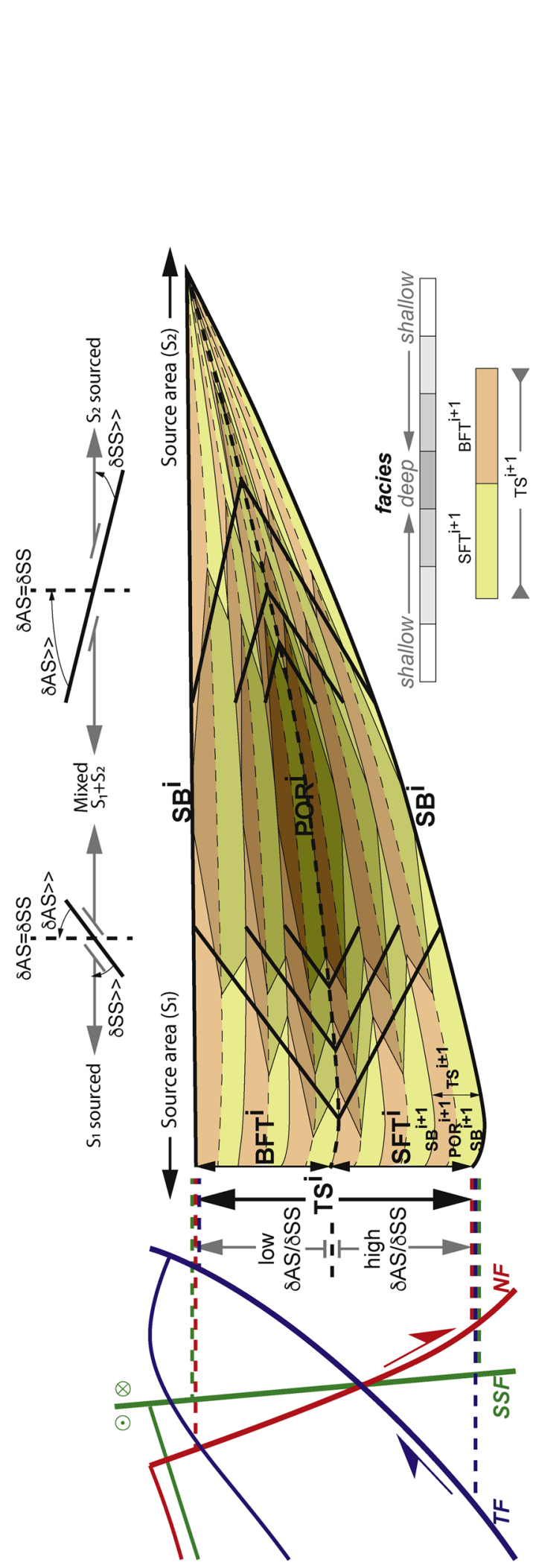

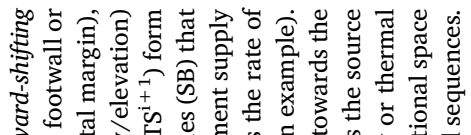

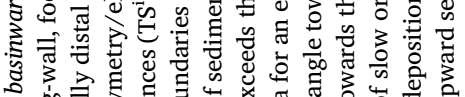

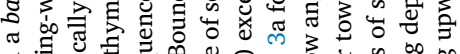

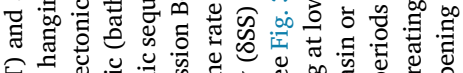

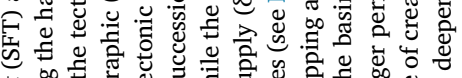

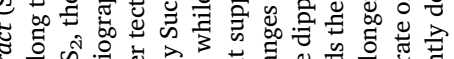

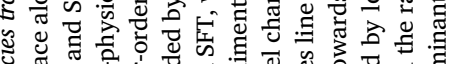

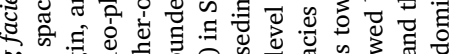

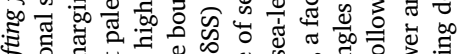

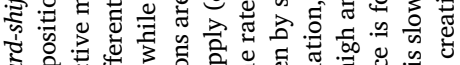

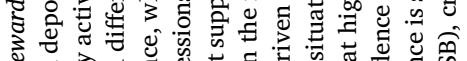

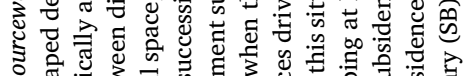

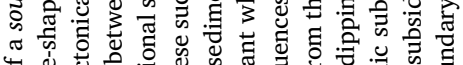

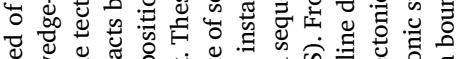

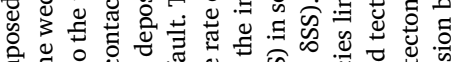

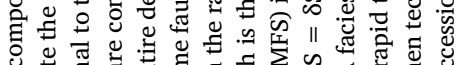

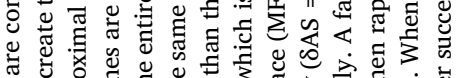

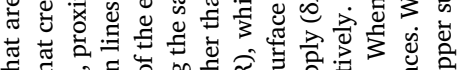

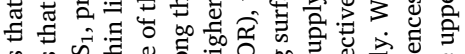

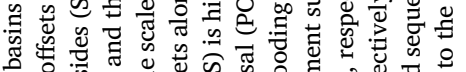

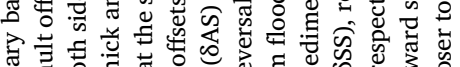

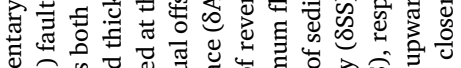

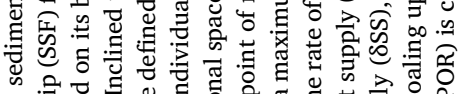

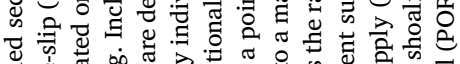

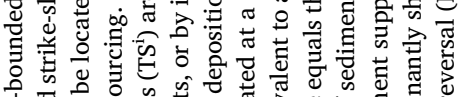

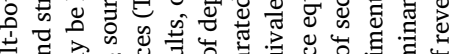

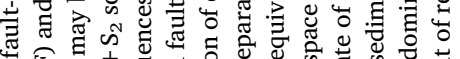

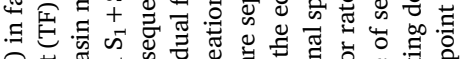

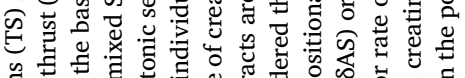

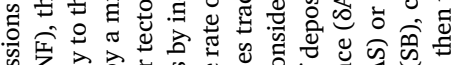

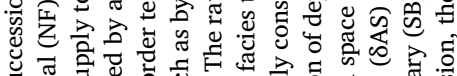

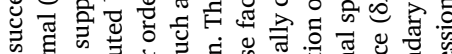

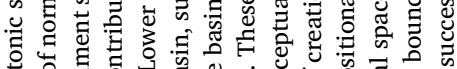

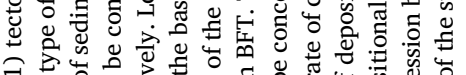

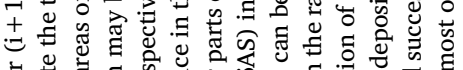

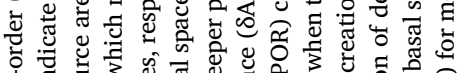

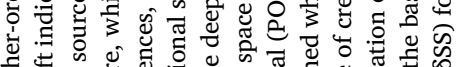

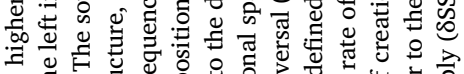

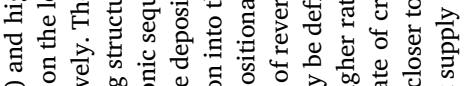

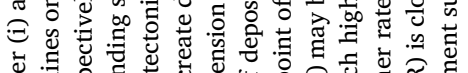

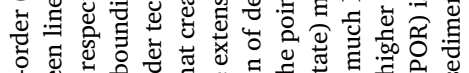

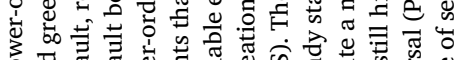

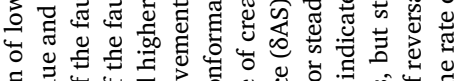

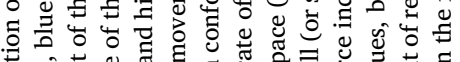

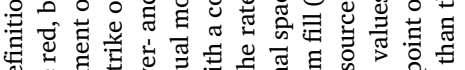

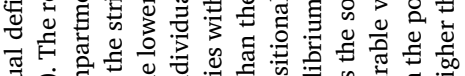

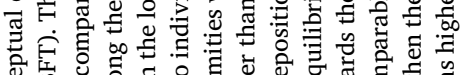

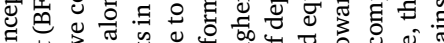

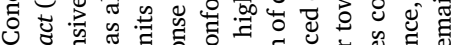
din

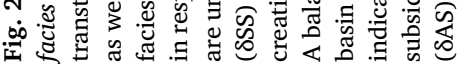




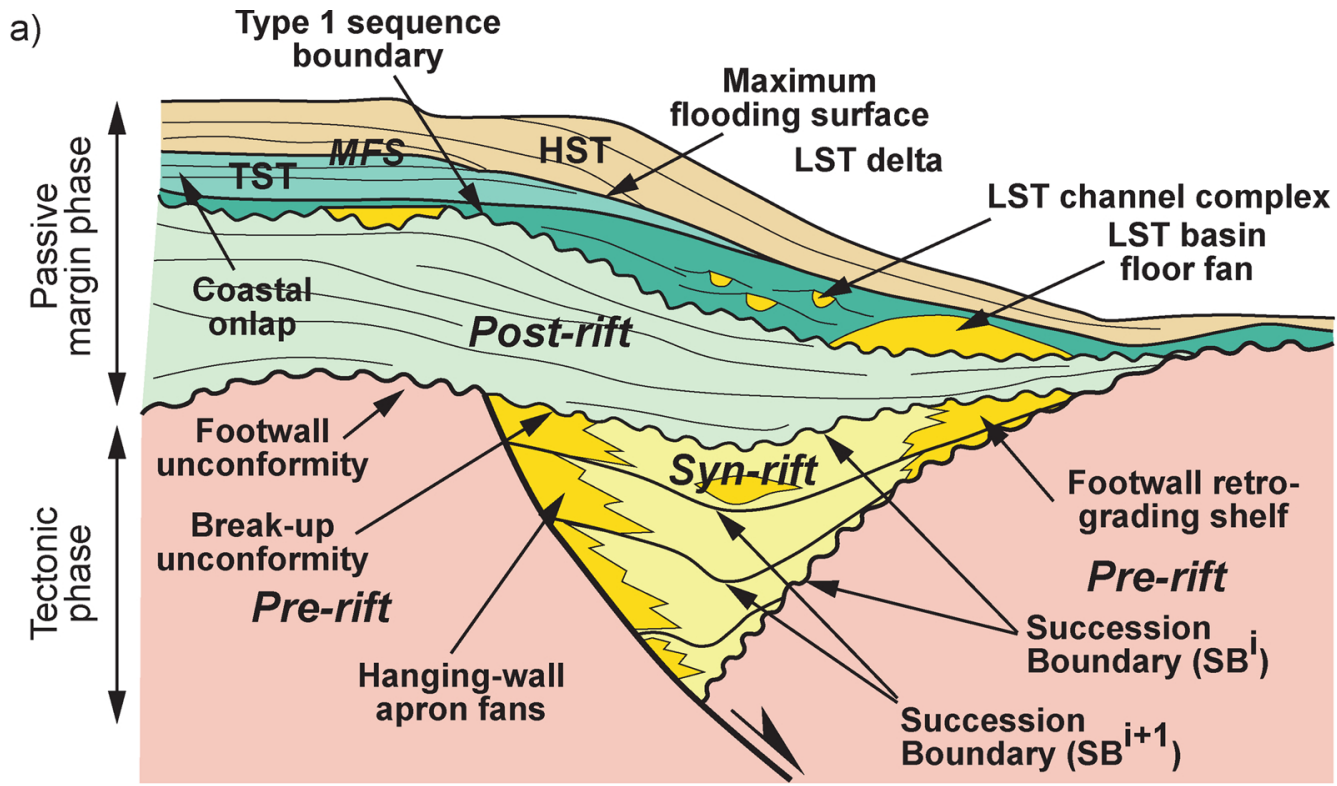

b)

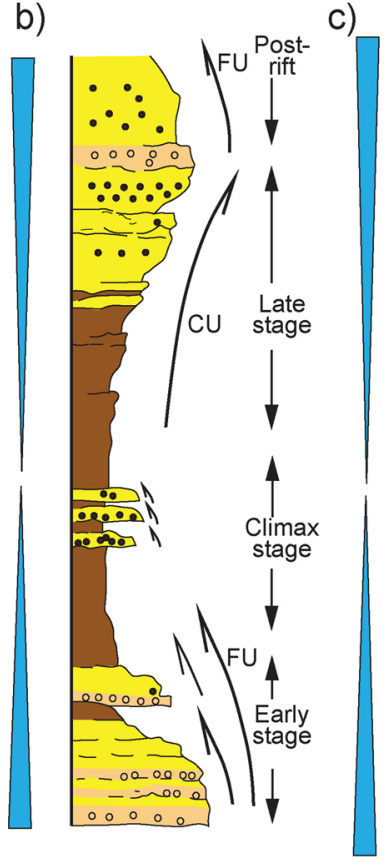

d)

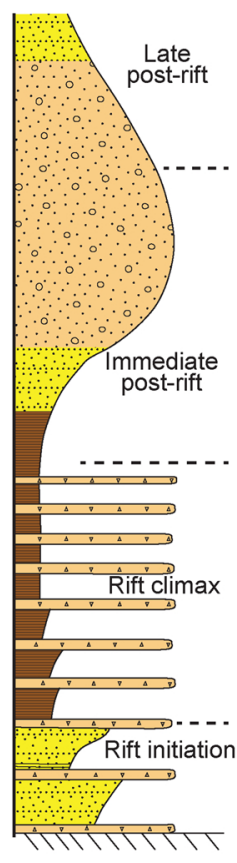

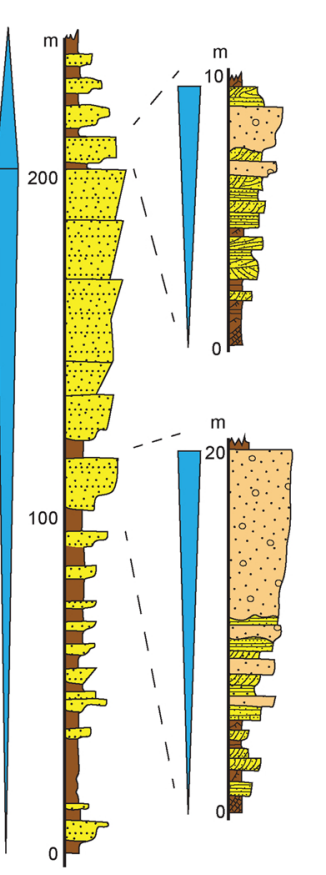

e)

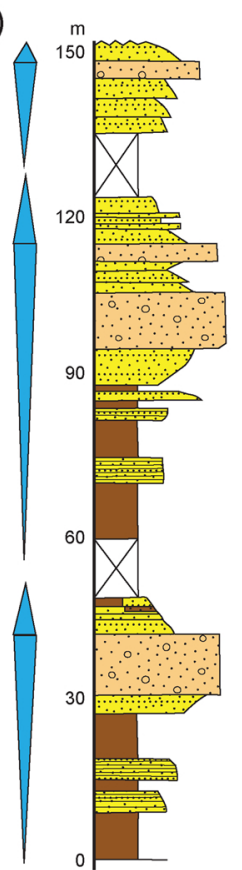

f)

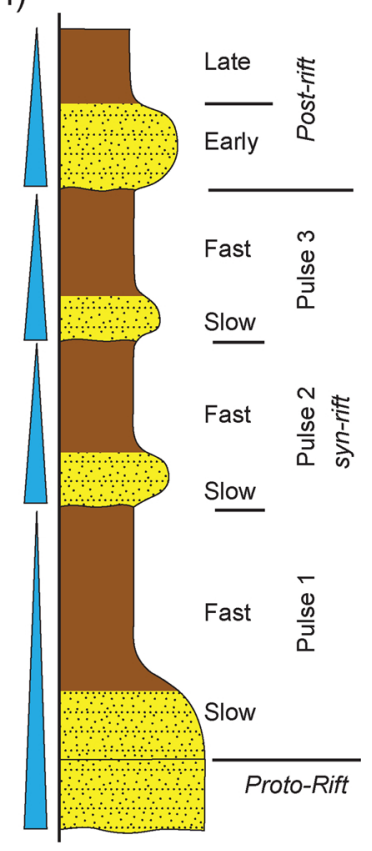

$$
\triangle \mathrm{SFT} \nabla_{\mathrm{BFT}} \therefore \text { conglomerates } \square \text { sandstones } \square \text { mudstones }
$$

Fig. 3. Conceptual models of sedimentation in extensional basins. a) Model of a continental rifting structure buried beneath the sediments of a passive continental margin (redrawn from Partington et al., 1993). In the lower part, sediments respond to moments of the normal fault activations by producing retrogradingprograding patterns detected by lateral facies changes. Mass-wasting deposits may be shed in the deeper parts of the basin by flows triggered by steepening of the half-graben flanks. In the upper part of the figure, a normal depositional sequence is illustrated that formed in response to sea level variations at a passive continental margin setting. This sequence is composed of a low-stand system tract (LST, made up by the basin floor fan, basin slope fan and LST delta) overlying a type 1 sequence boundary, followed by transgressive and highstand system tracts (TST and HST) separated by a maximum flooding surface (MFS). Figures b-f: various expressions of tectonic successions, illustrated in worldwide examples of rift basins. b) Schematic log of an idealized succession in a rift basin where accommodation and sediment supply are in balance (after Ravnas and Steel, 1998), creating early, climax, late and post-rift stages of sedimentation; c) Schematic log in a rift basin that marks the transition from continental to marine sedimentation (after Prosser, 1993). In this concept, the gradual deepening creates rift-initiation, rift-climax (early, middle and late) and post-rift (immediate and late) tectonic system tracts. These system tracts are in fact the expression of one rift-scale tectonic succession; d) Schematic log showing a coarsening-upward vertical stacking pattern that has been observed in some rift successions. The coarsening upward parasequences are separated by flooding surfaces, i.e. assuming instantaneous or rapid tectonics (after Frostick and Steel, 1993); e) Schematic log showing coarsening to fining upwards intervals in an alluvial - lacustrine syn-rift basin (after Martins-Neto and Catuneanu, 2010); f) Schematic log showing dominantly fining-upwards successions in offshore rift basins, associated with individual pulses of tectonic movement (after Nottvedt et al., 1995). 
a balance between the rate of creation of depositional space and the rate of sediment supply in a wide variety of environments, such as alluvial, lacustrine, and shallow and deep marine settings. Mass wasting becomes an important component in the deep-water environments due to steep slopes associated with normal faults, while the source of sediment supply is multi-directional, such as across the footwall, from the hanging-wall and along the strike of active normal faults (e.g., Alexander and Leeder, 1987; Leeder, 1991; Leeder et al., 1991; Gawthorpe et al., 1994; Gawthorpe and Leeder, 2000; Nixon et al., 2016). In all observed situations, movement along the fault controls the distribution of facies, and whether the basin will be underfilled, overfilled or balanced.

Conceptual stratal stacking models have been developed using seismic interpretations on passive continental (Atlantic type) margins, where syn-rift deposits were subsequently buried beneath post-rift sediments, the latter being commonly described using standard sequencestratigraphic nomenclature (Fig. 3a). Various stratal stacking models have been developed for the active stages of rifting assuming a general change in sedimentary environments from alluvial to lacustrine and to then to marine during the extension. Several phases of rifting are often distinguished: rift initiation, rift-climax and post-rift (alternatively subdivided as early, climax, late and post-rift stages) (Fig. 3b,c, Prosser, 1993; Ravnas and Steel, 1998; Răbăgia and Matenco, 1999; Pereira and Alves, 2012). In these schemes, the rift initiation phase is generally considered to be dominantly alluvial and sourced from the axis of the rift, wherein stacking patterns are dependent on facies associations (Fig. 3b,c). Increasing the rate of creation of depositional space by offsets against bounding normal faults that generate rapid subsidence leads to deeper marine facies intercalated with chaotic sediments from mass-wasting episodes sourced from the slopes created by normal faults and antithetic rotations of hanging walls. A gradual decrease in normal fault offsets results in a dominance of sediment supply over the creation of depositional space, while the basin may fill rapidly partially or completely. This scenario is likely during a transition from rifting to drifting and eventual conversion of the depocenter to a passive margin, or the abandonment of divergent motions (aborted rifts). The difference between various models is basically the capacity of the system to balance the rate of creation of depositional space during the induced change in sediment supply, resulting in a strong variability of the ratios between sedimentation during deepening and shoaling of the sedimentary system (Figs. 3d-f).

Such tectonically driven facies shifts can be envisioned at the scale of the entire rift sequence that are dependent on the interaction between depositional space and sediment supply, up to the point of onset of marine transgression in the basin. This scenario corresponds with our lower order tectonic succession bounded by succession boundaries $\left(\mathrm{TS}^{\mathrm{i}}\right.$ and $\mathrm{SB}^{\mathrm{i}}$ in Fig. 2). In fact, the rift initiation facies tracts (i.e., in the early stage) can be either a SFT onset, or cyclic, higher-resolution successions formed by interaction between changes in rates of sediment supply and depositional space during the early continental depositional phase (lower $\mathrm{TS}^{\mathrm{i}+1}$ successions during $\mathrm{SFT}^{\mathrm{i}}$ in Fig. 2). Thus, activation of successive slip movements along individual normal faults (or activation of successive normal faults in the same structure) can introduce higherorder cyclicity in the sediment fill of the rift systems. Such successive fault offsets have been long recognized to drive sedimentary cycles in the evolution of active or buried rifted systems, either at the scale of the entire basin or in individual sub-basins separated by uplifted areas, such as the East African Rift, the Canadian and Norwegian Atlantic passive continental margins, or the Pannonian back-arc extensional basin of Central Europe (e.g., Horváth and Royden, 1981; Enachescu, 1992; Mosar et al., 2002; Corti, 2008, 2009; Matenco and Radivojević, 2012 and references therein).

Models of individual fault offsets assume either long-lived movement of fault evolution dominated by fining-upwards sequences (Fig. 3f, e.g., Nottvedt et al., 1995), or conversely, instantaneous activation of normal faults (i.e., rapid creation of depositional space) resulting in flooding surfaces separating coarsening-upwards stacked sediments (Fig. 3d, Martins-Neto and Catuneanu, 2010). These are obviously extreme end member scenarios where either the rate of creation of depositional space or the rate of sediment supply are extreme, preventing the detection of deepening-upwards or shoaling-upwards components of the cycle. In practice, development of these components is characterised in sequence-stratigraphic terms in extensional basins (Fig. 3e, Frostick and Steel, 1993). These overall deepening- and shoaling-upward couplets are indeed compatible with our higher-frequency tectonic successions composed of higher-order sourceward- and basinward-shifting facies tracts $\left(\mathrm{TS}^{\mathrm{i}+1}, \mathrm{SFT}^{\mathrm{i}+1}\right.$ and $\mathrm{BFT}^{\mathrm{i}+1}$ in Fig. 2).

Numerous illustrative examples of tectonic depositional successions are available in extensional basins worldwide, where these can be identified on exploration seismic profiles, often combined with detailed facies analysis in outcrops and on well logs. Several such examples come from the Mediterranean, where the rapid roll-back of subducted slabs towards the orogenic foreland (as in the case of the Carpathians, the Hellenides or the Betics-Rif) has created extensional back-arc systems where individual basins were activated by the gradual migration in space and with time with similar trajectories, such as in the Pannonian, the Aegean or the Alboran areas (e.g., Horváth et al., 2006; Vergés and Fernàndez, 2012; Jolivet et al., 2013). The rapid extensional evolution of such back-arc systems was generally associated with deposition at rates that were high enough for the moments of fault offsets to be captured at the resolution of seismic lines (e.g., Matenco and Radivojević, 2012; Do Couto et al., 2016).

In the Pannonian Basin, the extension had started at $\sim 20$ Ma during the rotations associated with the eastward migration of the Carpathians arc that resulted in the formation of successive extensional half-grabens, which mostly become younger in the same direction (Horváth et al., 2015; Balázs et al., 2016). The overall evolution of these halfgrabens was associated with the deposition within a lower-order tectonic rifting cycle at the scale of the entire structure that recorded the transition from continental alluvial and lacustrine to marine and back to lacustrine facies during the gradual opening and closure of the Central Paratethys basins (Fig. 4a, Rögl, 1999; ter Borgh, 2013; Balázs et al., 2016; Sant et al., 2017). Migration of normal faulting during rifting induced lateral displacements in the early-rift phase deposition, as compared with the later rift phases (Fig. 4a). These three components of the sub-basin fill together constitute a lower-order tectonic succession that was deposited within 1.5-2 Myr (TS ${ }^{\mathrm{i}}$, Figs. 2 and $4 \mathrm{a}$ ). In this lower-order tectonic succession, the SFT comprises the rift-initiation and rift-climax deposition, while the BFT is made up by post-rift sediments that continued until the middle Miocene unconformity that was caused by basin inversion during the peak of Carpathians collision (Fig. 4a). Superposed on this lower-order tectonic succession, a higherorder tectonic periodicity, comprising sourceward- and basinwardshifting facies tract cycles is observed, which is expressed as migration of lobes, clinoforms and divergent seismic facies units (Fig. 4a) that correlate with a lateral deepening of sedimentary facies in well logs (Balázs et al., 2016). These higher-order tectonic cycles were controlled by individual movements of offset along the basin boundary fault and are fitting examples of higher-order tectonic successions composed of thinner SFTs and BFTs $\left(\mathrm{TS}^{\mathrm{i}+1}\right.$ in Fig. 2). These higher higher-order tectonic successions were deposited within 300-400 Kyr. Such durations are rather common for rapidly developing extensional back-arc or intramontane basins, such as for instance observed in the SarajevoZenica Basin of the Dinarides orogen (Andrić et al., 2017).

In other situations, higher-order tectonic successions may form in response to successive activations of multiple normal faults in the same half-graben structure, as in the case of the Malaga Basin in the western Mediterranean. This basin is part of the larger Alboran domain that formed during the Miocene back-arc extension associated with the westward roll-back of the Gibraltar slab and the formation of the BeticsRif orogenic system, which recorded significant inversion after $\sim 8 \mathrm{Ma}$ 


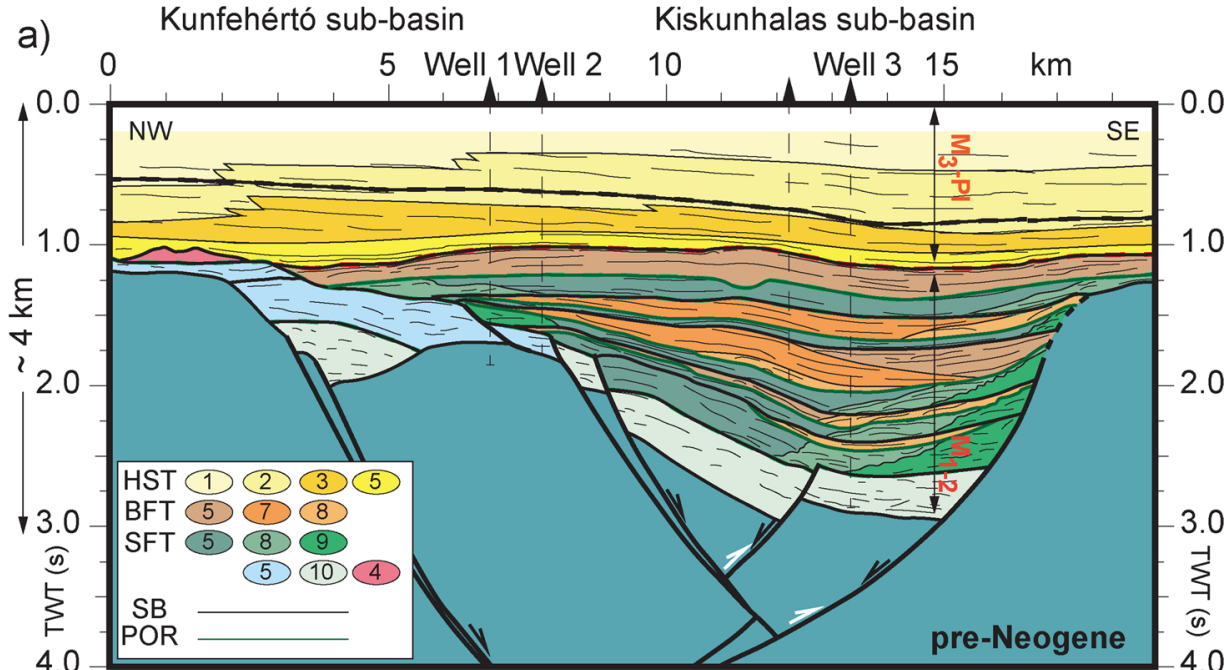

b) 0

10 Malaga basin 20

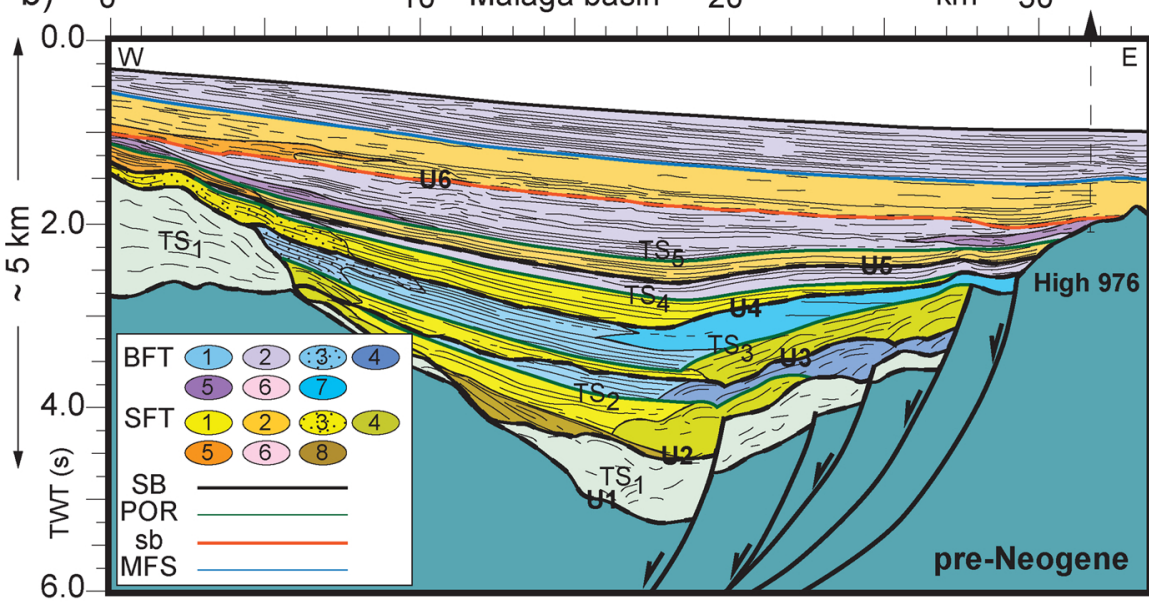

Fig. 4. a) Line-drawing interpretation reflection seismic line from the Kiskunhalas Trough of the Pannonian Basin (after Balázs et al., 2016). Black arrows indicate the Miocene kinematics of faults, white arrows show the late Middle-early Late Miocene inversion kinematics. The interpretation illustrates the interplay between a lower-order tectonic succession separated by basal and top (red line) succession boundaries (unconformities) and higher order tectonic successions created by individual movements along the basin boundary fault; b) Interpreted seismic reflection line from the Malaga Basin (internal Betics-Rif system, after Suades and Crespo-Blanc, 2013; Suades Sala, 2015). U are unconformities, RST and TST are regressive and transgressive system tracts, respectively; red arrows illustrate movements along individual normal faults. The interpretation illustrates the interplay between a lower-order tectonic succession separated by basal (U1) and top (U6) succession boundaries unconformities and higher order tectonic successions (TST-RST cycles) created by the activation of individual normal faults composing the deformation system near the High 976. C) Seismic line in the North Malay Basin located in the Gulf of Thailand (after Morley and Westaway, 2006). The fault-bounded part of the seismic line illustrates a good example where high-order tectonic successions and succession boundaries $\left(\mathrm{TS}^{\mathrm{i}+1}\right.$ and $\mathrm{SB}^{\mathrm{i}+1}$ ) may be discriminated from the low-order tectonic successions and succession boundaries $\left(\mathrm{TS}^{\mathrm{i}}\right.$ and $\mathrm{SB}^{\mathrm{i}}$ ) based on lateral variations of seismic facies that mirrors changes in lithofacies (For interpretation of the references to colour in this figure legend, the reader is referred to the web version of this article).

c)

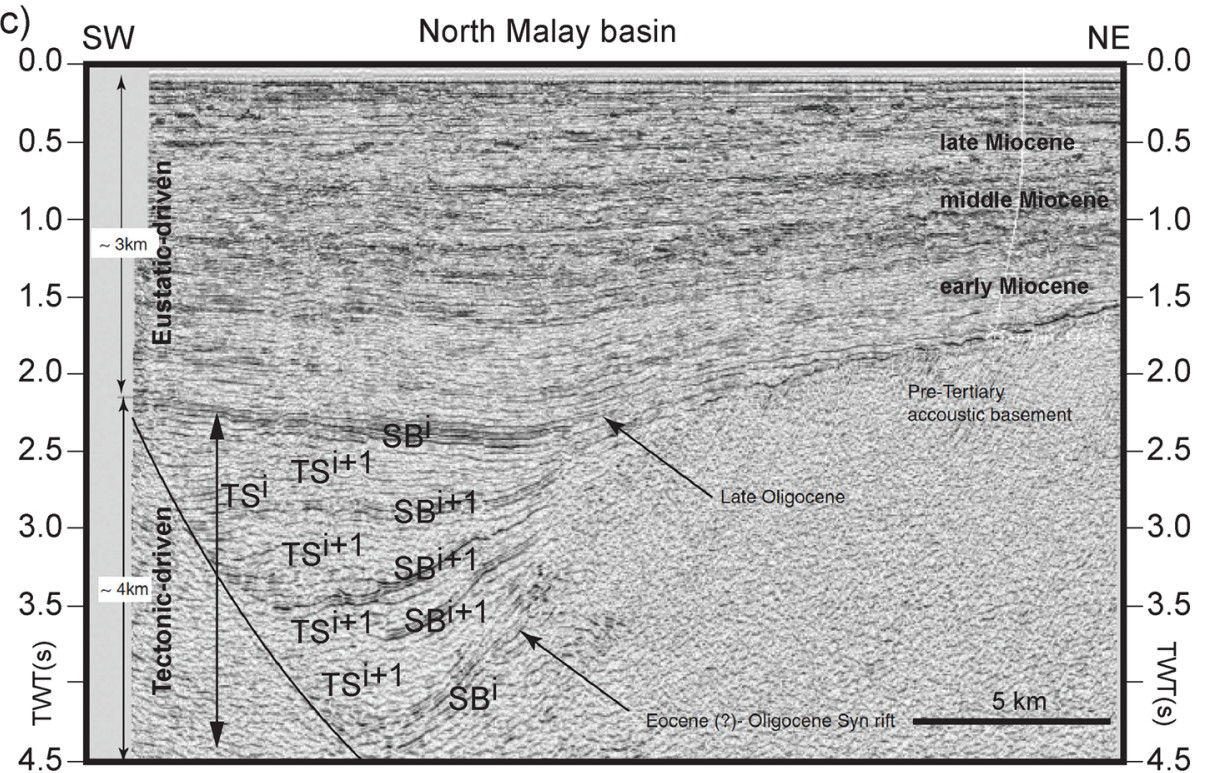

(Vergés and Fernàndez, 2012; Vissers, 2012; Platt et al., 2013; van Hinsbergen et al., 2014). Recent studies have shown that the Malaga Basin is a large half-graben system where its eastern flank is made up of a succession of $\mathrm{W}$ to NW-dipping normal faults that are most likely rooted at depth in a larger detachment structure, while the basin recorded less to no inversion after $8 \mathrm{Ma}$ along its NW and N areas (Fig. 4b, Comas et al., 1992; Watts et al., 2007; Suades and Crespo-Blanc, 2013; Suades Sala, 2015; Do Couto et al., 2016). The activation of each 
a)

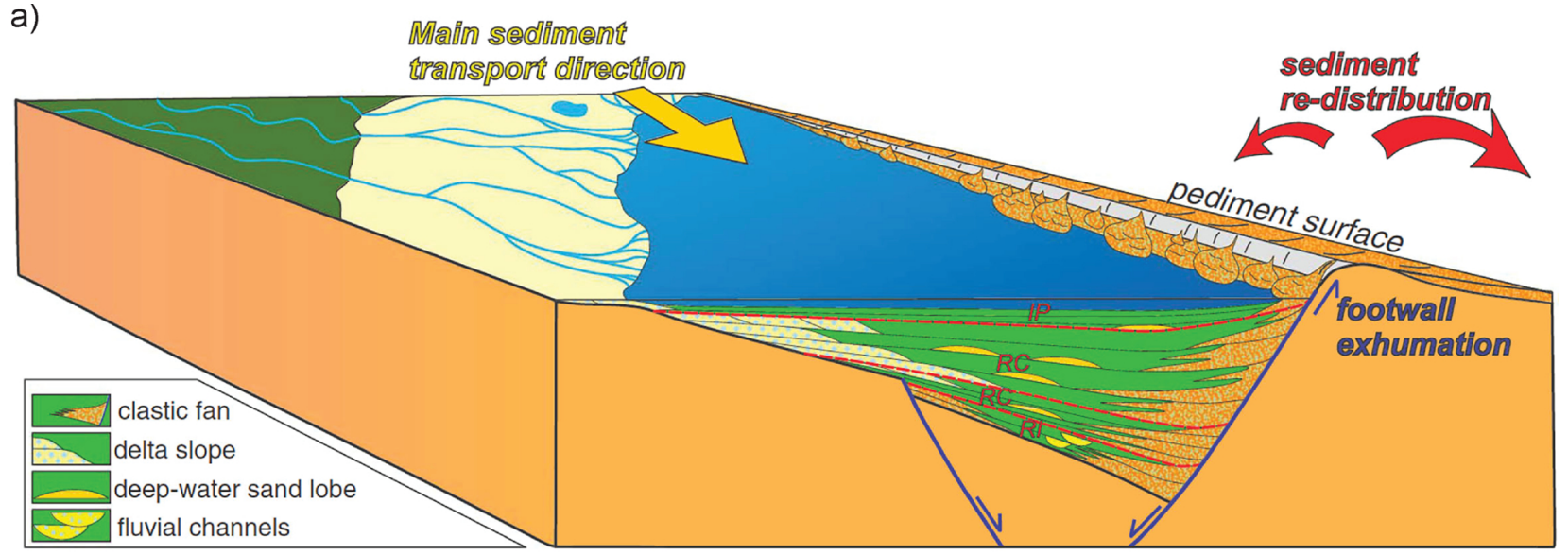

b)

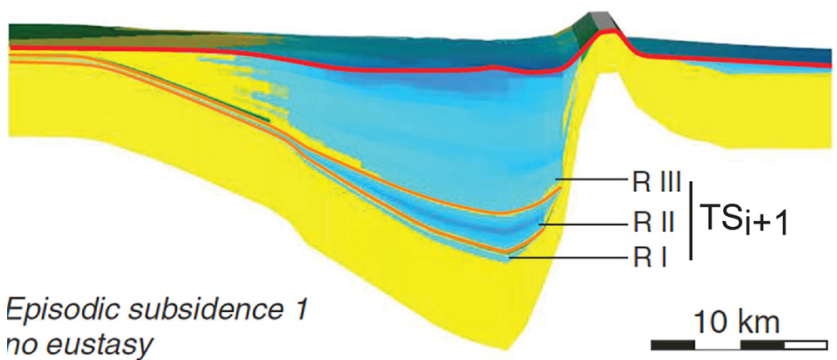

c)

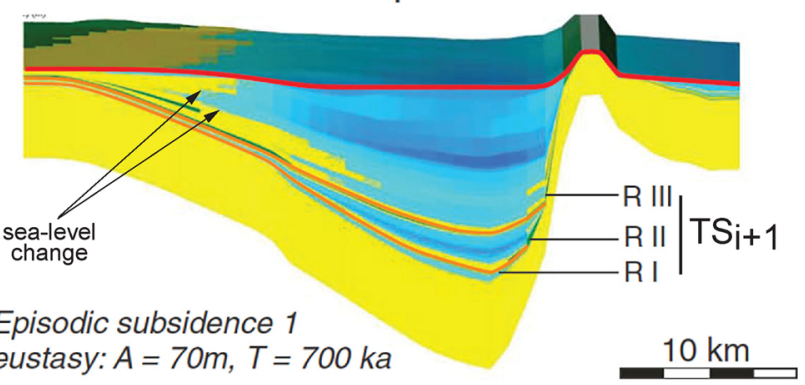

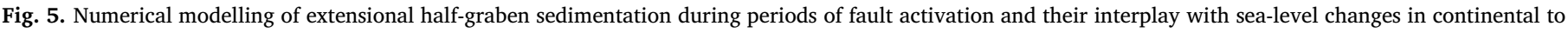

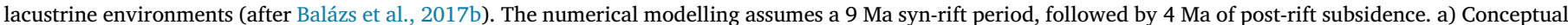

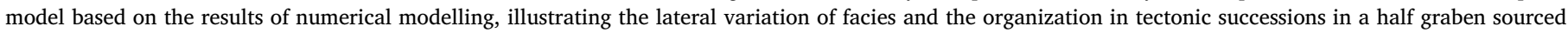

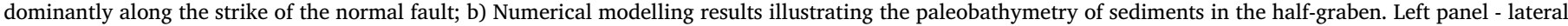

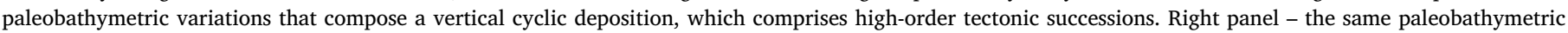

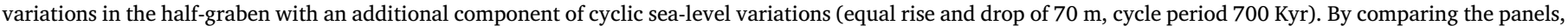
we note the clear distinction between high-order tectonic successions and lower order variations induced by sea-level change.

flanking normal fault creates an overall sourceward- to basinwardshifting facies tracts pattern that can be detected by the migration of lobes, sigmoidal and tabular facies units that are equivalent to the formation of individual $\mathrm{TS}^{\mathrm{i}+1}$ tectonic successions (Fig. 4b). Within the larger Malaga Basin structure, these units comprise a gradual transition from rift-initiation to climax to post-rift that is bounded by a basal transgressive unconformity and an upper unconformity (U1 and U6 in Fig. 4b) that constitutes a lower-order $\mathrm{TS}^{\mathrm{i}}$ tectonic succession. While the overall lower-order tectonic succession was deposited within 14-15 Myr, the high-order tectonic succession associated with the activation of individual faults (TS2-5 in Fig. 4b) were individually deposited within variable time intervals that span from 1.5 to $4 \mathrm{Ma}$. The U6 unconformity marks the onset of the Messinian Salinity Crisis (MSC) in the Malaga Basin and, therefore, separates a tectonic succession in its lower part from an upper eurybatic sequence driven by the large late Messinian sea-level drawdown.

In other situations, in a wholly continental environment, all or most of a lower-order tectonic succession of an extensional basin and the high-order movements of individual normal faults can be associated with deposition in an alluvial to lacustrine transition. Such is the case of many faults-bounded Oligocene to mid Miocene basins in or bordering the South China Sea (e.g., Morley and Westaway, 2006; Mansor et al., 2014; Morley, 2014; Pubellier and Morley, 2014). Here, the transition from continental to deep marine environment did not occur, though such a transition is often the case in typical tectonic successions where facies vary from shallower to deeper settings. Good examples have been described from the Gulf of Thailand, such as the Pattani Basin or the lower infill of the Malay Basin (Fig. 4c, Morley and Westaway, 2006).
These shallower to deeper transitions are seen in the Oligocene to mid Miocene successions comprising alluvial fan, fluvio-deltaic and lacustrine facies at the scale of individual sub-basins. The (late - Eocene?) Oligocene syn-kinematic infill of the north Malay Basin ( 6-7 Myr) forms a lower order tectonic succession (TS ${ }^{\mathrm{i}}$ ) was covered by post-rift late Oligocene - early Miocene lacustrine shales (Fig. 4c). Individual movements of normal faults activation that lasted 1-1.5 Myr, are discernible as higher order tectonic successions $\left(\mathrm{TS}^{\mathrm{i}+1}\right)$ on seismic imagery, where they are represented by changes of slope lobes that interfinger with more distal pelagic facies, separated by strong reflective unconformities that make up the higher-order succession boundaries $\left(\mathrm{SB}^{\mathrm{i}+1}\right.$, Fig. 4c).

Process-oriented numerical modelling of sedimentation is also well suited to illustrate our conceptual model of tectonic successions in extensional basins. Such studies are available either at the scale of whole extensional systems, where they exemplify lower-order tectonic successions (e.g., Embry, 1990; Kooi et al., 1992; Kusznir et al., 1996; Burov and Cloetingh, 1997; Meredith and Egan, 2002; Cloetingh et al., 2013), or at the higher-order scale of individual sub-basins or individual normal fault structures (e.g., Csato and Kendall, 2002; Balázs et al., 2017b; Barrett et al., 2018). Numerical modelling of sediment infill in asymmetric extensional half grabens can discern the development of high-order tectonic successions (associated with sourceward and basinward facies shifts) that can be discriminated from other external forcing factors such as low-amplitude eurybatic sea-level variations (or climatic effects) that show more regular shallowing-deepening patterns in the stratal architecture (Fig. 5). It is also clear that the signature of eustatic influence within this record is discernible only at a 


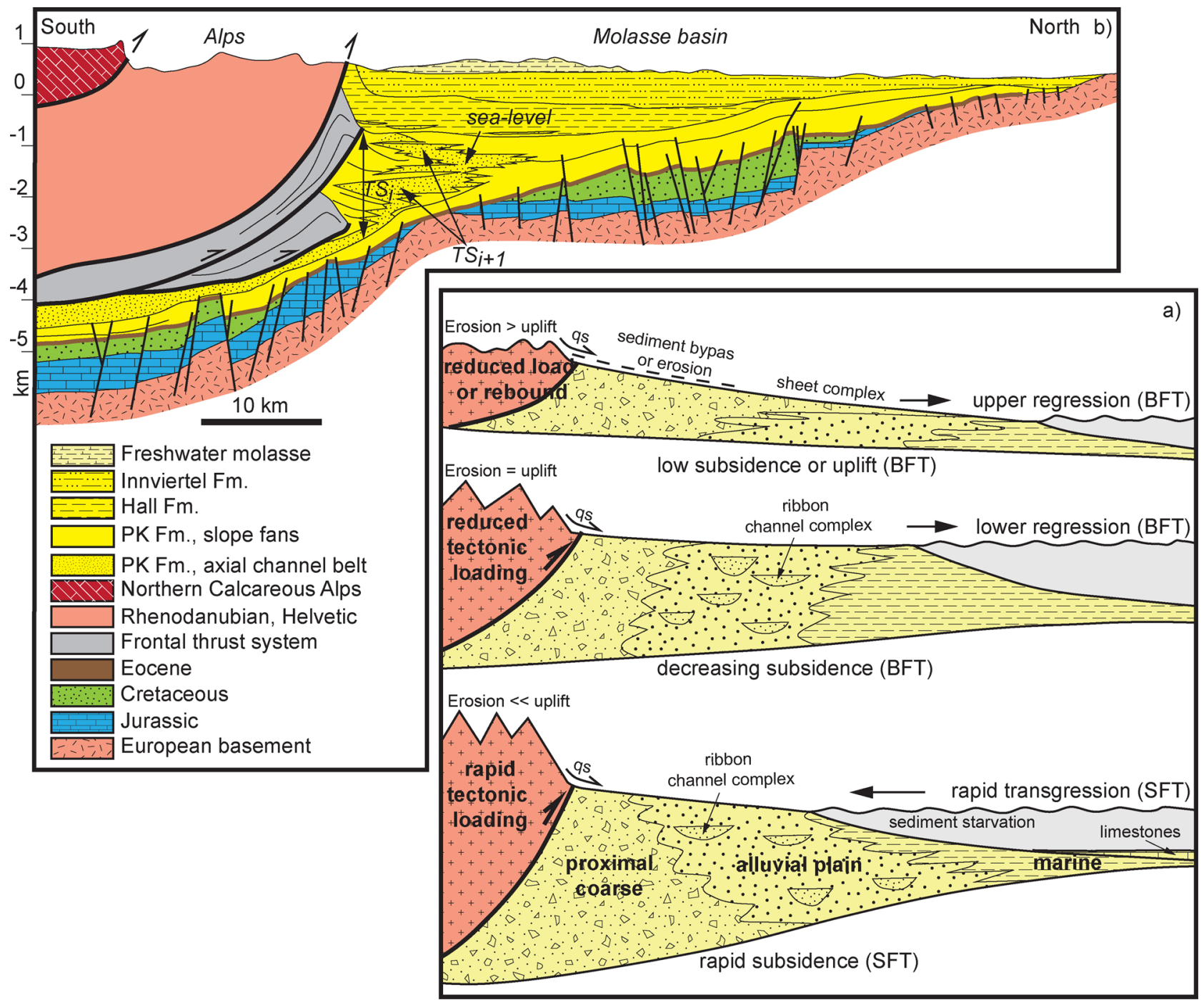

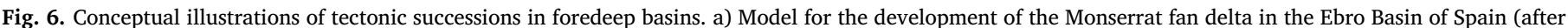

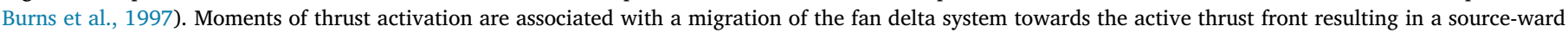

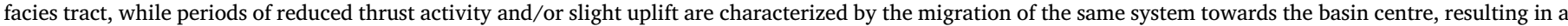

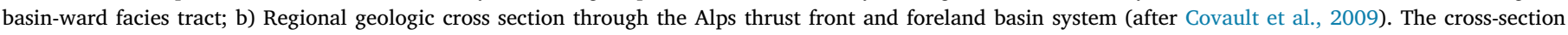

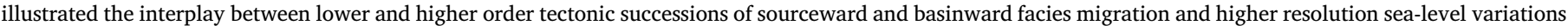
recorded by the basin.

scale that is at a different order of magnitude than the one of tectonic forcing (Fig. 5, Balázs et al., 2017a, b).

\subsection{Contractional basins}

Most contractional basins are related to orogenic areas where depositional space is created by tectonic loading during thrust and nappe emplacement associated with the growth of mountain ranges. It has been long recognized that such loading results in creation of significant depositional space due to the flexure of oceanic and continental lithosphere undergoing subduction, forming accretionary wedges and forearc or back-arc foreland or foredeep basins, influenced by a large number of forcing factors (Beaumont, 1981; Royden and Karner, 1984; Allen et al., 1986; Stockmal et al., 1986; DeCelles et al., 1991; Watts, 1992; Wagreich, 1995; Ziegler et al., 1995; Fuller et al., 2006; Naylor and Sinclair, 2008; DeCelles et al., 2009, 2014; Noda, 2016). One difference of contractional basins from other types of basins is that continued convergence at the leading edge scrapes off the sediments deposited earlier in the flexural accommodation and incorporates them into the orogenic system as highly deformed accretionary prisms, external fold and thrust belts or deformed foredeeps, where depositional records may be sharply eroded. In the Mediterranean such is the case of accretionary wedges in the Herodotus and Ionian Basins, where the MSC evaporites and sediments (originally deposited horizontally) are scraped, in places highly thickened, and deformed (e.g., Güneş et al., 2018).

The understanding of movements of thrust loading in highly deformed systems requires careful reconstruction of the deformed strata to restore original depositional conditions as closely as possible (e.g., Morley, 1996; Vilasi et al., 2009; Tărăpoancă et al., 2010). Since the distribution pattern of sedimentary facies is a direct response to thrusting, it can be used to gain an understanding of the movements of thrust loading during subduction (e.g., Jordan et al., 1988; Ballato et al., 2008; Santra et al., 2013; Ballato et al., 2019, among many others). The recurrent arrangement of thrusts maintains a relative constancy in the orogenic geometry and as such these basins may have extensive continuity of hundreds to thousands of kilometres along the orogenic strike (e.g., Dahlstrom, 1970; Roure, 2008). Since the flexurally-created depositional space is asymmetric in response to the thrust load distribution, the geometry of such basins is notably wedge shaped, 


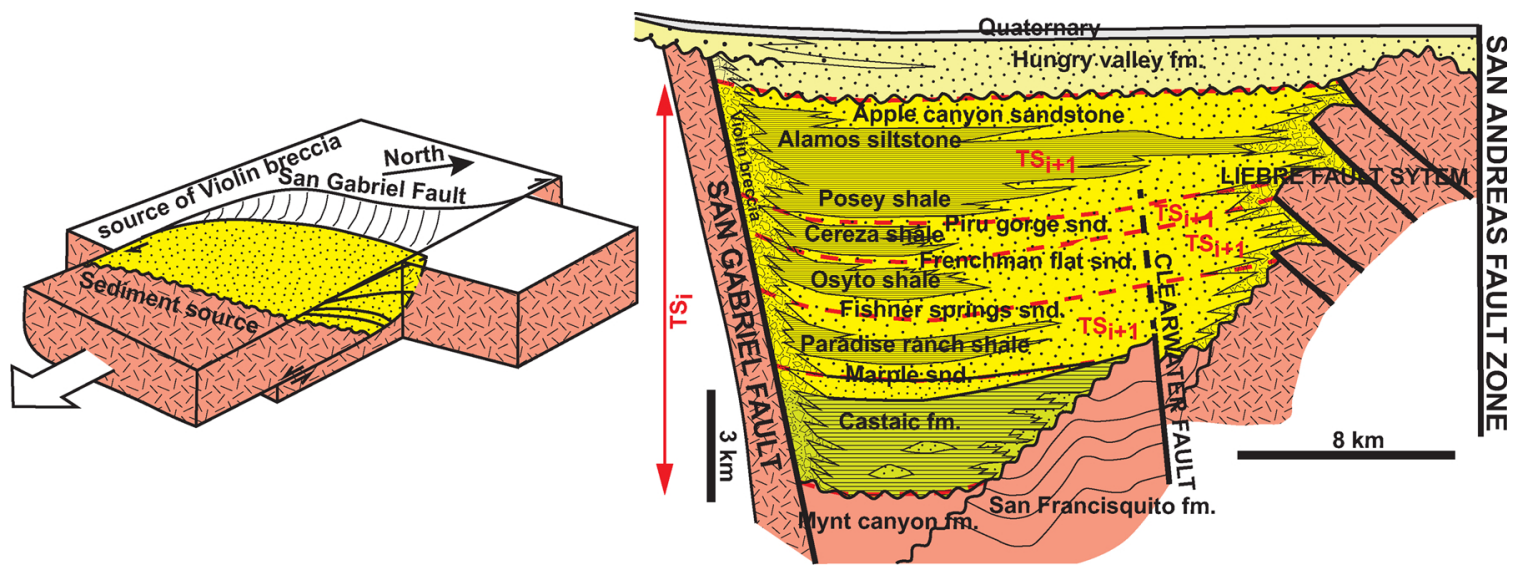

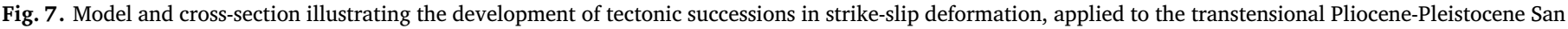

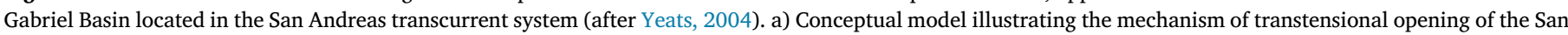

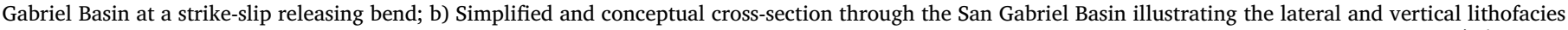

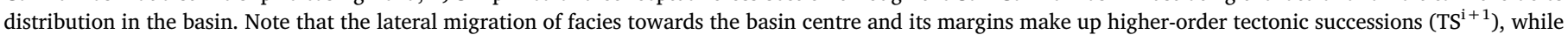
the fining and coarsening upwards patterns at the scale of the entire basin makes up a lower-order tectonic succession (TS ${ }^{\mathrm{i}}$ ).

changing over time due to shortening and sediment loading. It is primarily controlled by the flexural rigidity of the lithosphere that is undergoing subduction (Watts, 1989; Burov and Diament, 1992; GarciaCastellanos and Cloetingh, 2011). The most prominent grouping of tectonic successions in contractional basins is observed in collisional foredeeps formed during the final phases of orogenic convergences. Here the sediment cover over the continental lower plate is overlain transgressively above a diachronous unconformity in response to successive thrust loadings, followed by a shallowing-upwards phase of basin fill varying from lacustrine to alluvial sedimentation (the classical old term "molasse"). Such successions of complete basin fill have been described from many collisional orogens, such as those from the Alps, the Carpathians, the Caucasus and the Apennines (e.g., Homewood et al., 1986; Waschbusch and Royden, 1992; Ershov et al., 1999; Roure, 2008; Covault et al., 2009).

Several genetic sedimentation models (based mostly on seismic interpretations, combined with observations on well logs and outcrops) are available for foredeep basins (e.g., Fig. 6). Detailed sedimentological facies distribution studies demonstrate the importance of thrust loading in controlling the balance between the rate of accommodation creation and sediment supply (Bruhn and Steel, 2003; Catuneanu, 2004; Ford, 2004; Roca and Nadon, 2007). Such models are highly variable depending on the paleoenvironment (whether continental, shallow or deep marine) of the contractional basin (Einsele, 2000 and references therein). Some of these studies also demonstrate the increasing importance (during deformation) of the source of the basin fill from the foreland lower plate and along the strike direction that produces the mixed-source sedimentary successions observed in the infills (Oszczypko, 2006; Ridd, 2013). The study of foredeep dynamics is also key to detecting the history of orogenic movements further afield in the hinterland areas (Roure, 2008; Grool et al., 2018).

All of these models have one key observation in common; the facies deepen in the foredeep basin depocenters during thrust loading, while a shallowing-upwards phase of basin fill is recorded during the period of reduced or non-thrust activity that create the sourceward- and basinward-shifting facies tracts of our model (SFT ${ }^{\mathrm{i}+1}$ and $\mathrm{BFT}^{\mathrm{i}+1}$ in Fig. 2). This is exemplified by observations in the Ebro Foredeep of the Pyrenean Foreland Basin (e.g., Desegaulx and Moretti, 1988; GómezPaccard et al., 2012), where the movements of thrust activation are associated with the migration of a fan delta system (proximal gravels, alluvial plain and marine sediments) towards the active thrust front, while periods of reduced thrust activity and/or slight uplift are characterized by the migration of the same system towards the basin centre (Fig. 6a, Burns et al., 1997). The first period of source migration makes up the high-resolution SFT of our model, while the periods of decreasing and/or low subsidence or minor uplift, are equivalent to our BFT (Fig. 6a). This cyclicity observed in the Ebro Basin has also been validated by numerical modelling of sedimentation dynamics (GarciaCastellanos, 2002, 2006).

An illustrative example of tectonic successions and their interplay with sea-level changes at the scale of entire foreland basin comes from the northern Alpine foredeep (or the German-Austrian molasse/foreland basin) (Fig. 6b, Zweigel et al., 1998; Covault et al., 2009). Previous studies have shown that the basin fill was controlled by a major thrust loading and flexural subsidence event that took place during Late Eocene-Early Miocene times, which included the middle Oligocene transition from the classical "flysch" to "molasse" stages, possibly in response to the European slab break-off (e.g., Sinclair, 1997). This was followed by a phase of reduced subsidence that resulted in an overall shoaling-upwards sedimentation that filled the basin. Thrusting resulted in both the creation of depositional space in the footwall and the formation of a connected wedge-top (or piggy-back) basin overlying the hanging-wall, which provided the source of sediments including the mass-wasting deposits. The interplay between the tectonic subsidence and sediment supply controlled the large-scale deepening- and shoaling-upwards megacycles within 6-7 Myr, while higher-order unconformities were related both to sea-level variations (sequence boundaries) and thrust loading events (successions boundaries) that took place most likely within 1-2 Myr time intervals (Fig. 6b, Zweigel et al., 1998; Covault et al., 2009; Knierzinger et al., 2018). Such models of thrust-loaded sourceward and basinward migration of sedimentary facies ( $\mathrm{TS}^{\mathrm{i}+1}$ successions) have been also validated by numerical modelling of the foredeep evolution (e.g., Clevis et al., 2004).

\subsection{Strike-slip basins}

Strike-slip basins develop along key transcurrent boundaries, where major displacements occur in the horizontal plane due to either rightor left- lateral movements. In these tectonic settings, depositional space is created by secondary normal offsets that take place along the major fault bends (i.e., releasing bends, e.g. Fig. 7a) when horizontal offsets are transferred between two or more strike-slip faults (pull-apart basins), or through a combination of these two mechanisms (e.g., Mann et al., 1983; Christie-Blick and Biddle, 1985; van Wijk et al., 2017). Many such basins are known to be associated with major strike-slip offsets that display tens to hundreds of $\mathrm{km}$ of horizontal displacement. Well-known examples are along the San Andreas Fault system in western United States, the North Anatolian Fault in northern Turkey, the 

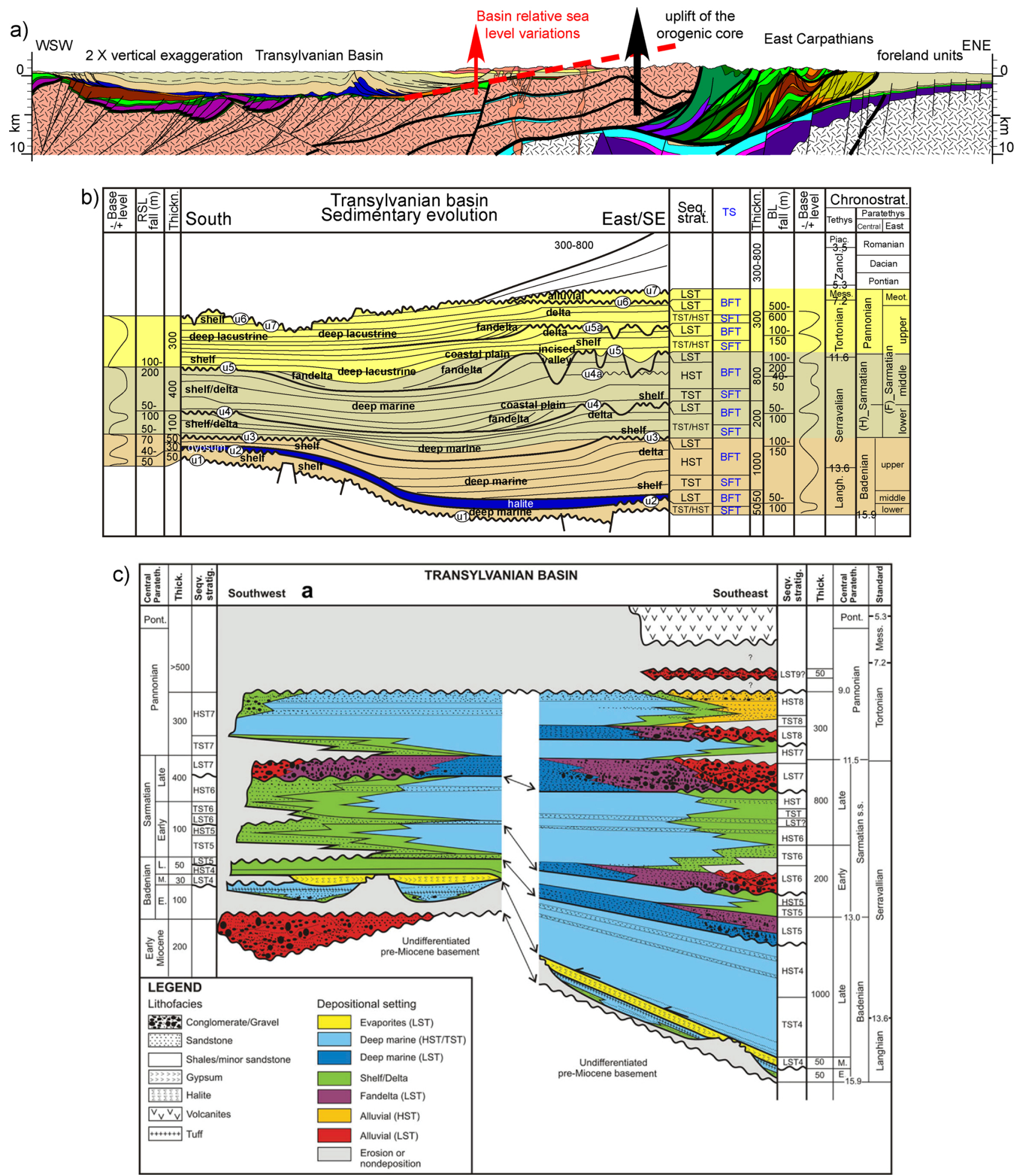

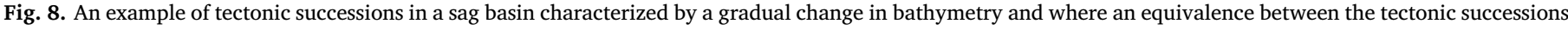

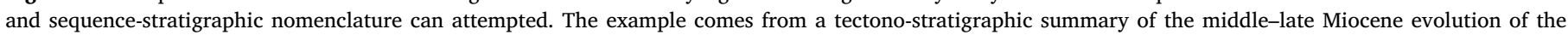

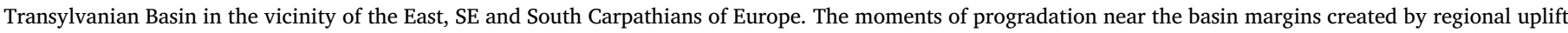

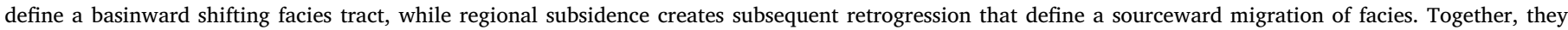

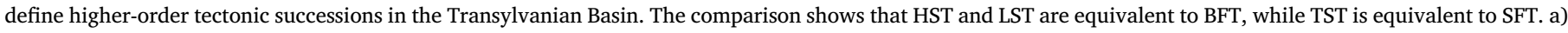

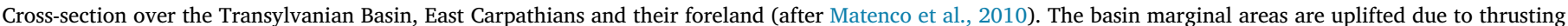

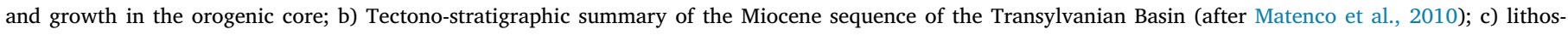
tratigraphic summary of the Miocene sequence of the Transylvanian Basin (after Krézsek et al., 2010).

Alpine Fault of New Zealand, and the Cerna-Timok Fault system of the Carpathians (Okay et al., 2000; Barnes et al., 2005; McLaughlin and Nilsen, 2006; Schmid et al., 2008; Krézsek et al., 2013). Limited to bends or transfer zones along major strike-slips these sedimentary basins are spatially restricted, with limited lateral continuity and large variability in the sedimentary infill. Because a small amount of 
transcurrent offset generates a large vertical displacement component, strike-slip basins can fill rapidly with thick sedimentary successions that are sourced from the vicinity of the main left- or right-lateral fault from multiple directions. The strike-slip bounding faults are generally steep and get rapidly degraded by erosion, filling the basin with coarse fault breccias in the vicinity, while transtension can generate normal faults that may be associated with deepening and fining upwards to shoaling and coarsening upwards prisms of sediments.

The San Andreas transcurrent system of western North America provides one well-documented example where spatially limited transtensional basins are located along the sinuous trace of the strike slip fault. Located in the middle of the California's Transverse Ranges and comprised of a system of transpressional mountains and transtensional basins, the San Gabriel Basin is a Pliocene-Pleistocene basin formed through dextral transtension along the San Gabriel Fault that is a part of the larger San Andreas Fault system (Fig. 7a, May and Walker, 1989; Nourse, 2002; Yeats, 2004). A thick breccia was deposited in the vicinity of the San Gabriel Fault and a lesser one on the opposite flank of the basin, while the general composition of the basin displays deepening-upwards and shoaling-upwards facies shifts that were generated by the activity of the strike-slip system. This variation in facies and sediment influx farther into the basin is an example of the alternation between higher-order SFTs and BFTs comprising tectonic successions, lasting anywhere between $500 \mathrm{Kyr}$ and $1 \mathrm{Myr}$, driven by the transtensional activity of marginal controlling faults $\left(\mathrm{TS}^{\mathrm{i}+1}\right)$. Following the Miocene precursor deposition, the entire Pliocene-Pleistocene basin makes up an overall $\mathrm{TS}^{\mathrm{i}}$ lower-order tectonic succession (Fig. $7 \mathrm{~b}$, see also Yeats, 2004). It is noteworthy that the gradual opening of such a basin along the strike of a major transcurrent fault generates a basin fill where depocenters of tectonic successions are laterally displaced in the same direction. One typical example is provided by the Oligocene-Early Miocene basin formation stage of the Cerna-Timok dextral fault system in the South Carpathians, where the younger transtensive basins formed eastwards in the releasing bend direction of the main controlling faults (Ratschbacher et al., 1993; Răbăgia and Matenco, 1999; Krézsek et al., 2013).

\subsection{Tectonic-induced uplift}

Similar to the tectonically created depositional space discussed above, diastrophic processes may also reduce or wipe out such space by uplifting part or the entire infilled basin. This is a typical evolution in plate tectonics, where rifts are created and buried beneath passive continental margins that are subsequently uplifted and incorporated in orogens during subduction and/or collision (e.g., Ziegler et al., 2002). Inversion commonly occurs in extensional basins due to transient processes or a switch from divergent to convergent movements (e.g., Williams et al., 1989). Extensional back-arc basins formed during slabretreat are commonly uplifted and/or inverted during the final phases of collision and slab-detachment (Uyeda and Kanamori, 1979; Matenco et al., 2016). Large parts of foreland basins are scraped-off and incorporated into fold and thrust belts by on-going subduction or convergence, where the depositional space gradually diminishes followed by subaerial exposure and erosion in fore-arc or wedge top (piggy-back) basins (e.g., DeCelles and Giles, 1996; Ford, 2004; Noda, 2016).

The analysis of sedimentary facies shows that deposition associated with tectonic uplift is controlled by a relative base-level drop that creates forced-regressive type sedimentary patterns that are localized at the active margin of the basin. In our tectonic succession model, this means that at the onset and during the subsequent major tectonic movements BFTs will dominate, while during the gradual decrease in fault offset or quiescence SFTs will be the common norm. A good example of such a case is provided by the Miocene evolution of the Transylvanian Basin, a sag basin located in the hinterland of the Romanian Carpathians (Fig. 8). The retreat of the Carpathians slab resulted in the onset of the successive phases of subsidence recorded in the basin centre during middle Miocene times (Krézsek and Bally, 2006; Tiliţă et al., 2013, 2015). The margins of the basin recorded successive uplift events due to gradual orogenic exhumation during the final collisional phases of South and East Carpathians (Matenco et al., 2016). Application of sequence-stratigraphic concepts to these margins revealed that each phase of uplift was associated with forced-regressive type patterns with local unconformities at the basin margins, overlain by transgressive facies associated with the regional subsidence of the entire basin (Fig. 8, Krézsek et al., 2010; Matenco et al., 2010). Sedimentation was interrupted subsequently by complete exhumation of the basin during late Miocene times. In the framework of our new model, the Miocene sediment fill can be reinterpreted: the period of regressive facies associated with tectonic uplift in the East and South Carpathians margins are higher-order BFTs $\left(\mathrm{BFT}^{\mathrm{i}+1}\right)$, while the periods of transgressive trends during regional subsidence can be categorised as higherorder SFTs $\left(\mathrm{SFT}^{\mathrm{i}+1}\right)$. These high-order tectonic successions have a variable duration, within $500 \mathrm{Kyr}-1.5 \mathrm{Myr}\left(\mathrm{TS}^{\mathrm{i}+1}\right.$, Fig. 8). Together, these higher-order facies tracts constitute a lower-order tectonic succession that lasted for around 6-7 Myr (TS $\left.{ }^{\mathrm{i}}\right)$. Similar examples are also available in observational or numerical modelling studies of wedge-top (or piggy-back) basins, which show that movements of hanging-wall uplift during thrusting induce migration of sedimentary facies towards the centre of the basin, while regional orogenic subsidence results in a migration of facies towards the basin margins (e.g., Nijman, 1998; Clevis et al., 2004; Răbăgia et al., 2011) comprising BFT-SFT couplets.

\subsection{Source area and mass-wasting deposits}

The position of various sediments in a sourceward- or basinwardshifting facies tract is controlled by their location in the paleo-physiography of the basin and not by their grainsize. In tectonically active areas an increased sediment yield is recorded from tectonically active (often small) watersheds, as pointed out by Milliman and Farnsworth (2011). Their work has demonstrated that high yields are a function of gradient and impact of episodic events in which both sediment supply and sediment transport can play and important role, and which can be especially exaggerated in the case of volcanic eruption events. The fact that there is no direct correspondence between physiography and grainsize is best illustrated by the deep-water mass wasting deposits, where coarse deposition is often triggered by fault activation that creates not only accommodation space, but also enhances the exhumation of the source area and modifies the topography that is subject to erosion. One example is the Miocene evolution of the Sorbas Basin of southern Spain that is a well-studied area for the interaction between tectonics, sea-level changes and orbitally-forced stratigraphy. Many recent mass-wasting models are based on outcrop observations in this basin (Krijgsman et al., 2001; Hodgson and Haughton, 2004; Do Couto et al., 2014; Andrić et al., 2018; Postma and Kleverlaan, 2018). Part of the larger extensional Alboran Domain that evolved in the hinterland of the Betics-Rif system, the lower infill of the Sorbas Basin displays highresolution tectonic successions $\left(\mathrm{TS}^{\mathrm{i}+1}\right.$ ) associated with individual movements along normal faults, where the depositional space and sediments sourcing is created either by fault offset, or by antithetically tilting hanging-wall blocks (e.g., Andrić et al., 2018). In deeper-water environments, such movements are marked by transition between slope to basin floor turbiditic fans, while coarser material temporary stored on shallow shelves is recycled in a hanging-wall direction toward the deeper-water environments by various types of mass-wasting events during movements of fault-offset associated with antithetic tilting (Fig. 9). Such high-order tectonic sedimentary successions may also be sourced across footwalls or along the strike of normal faults and are most often associated with severe erosional degradation of faults footwalls (e.g., Henstra et al., 2016; Alves and Cupkovic, 2018). The result is that coarser deposits are sourced in deeper water environments during moments of fault activation, enhanced by an increased output from the source area and availability of such material in temporary 


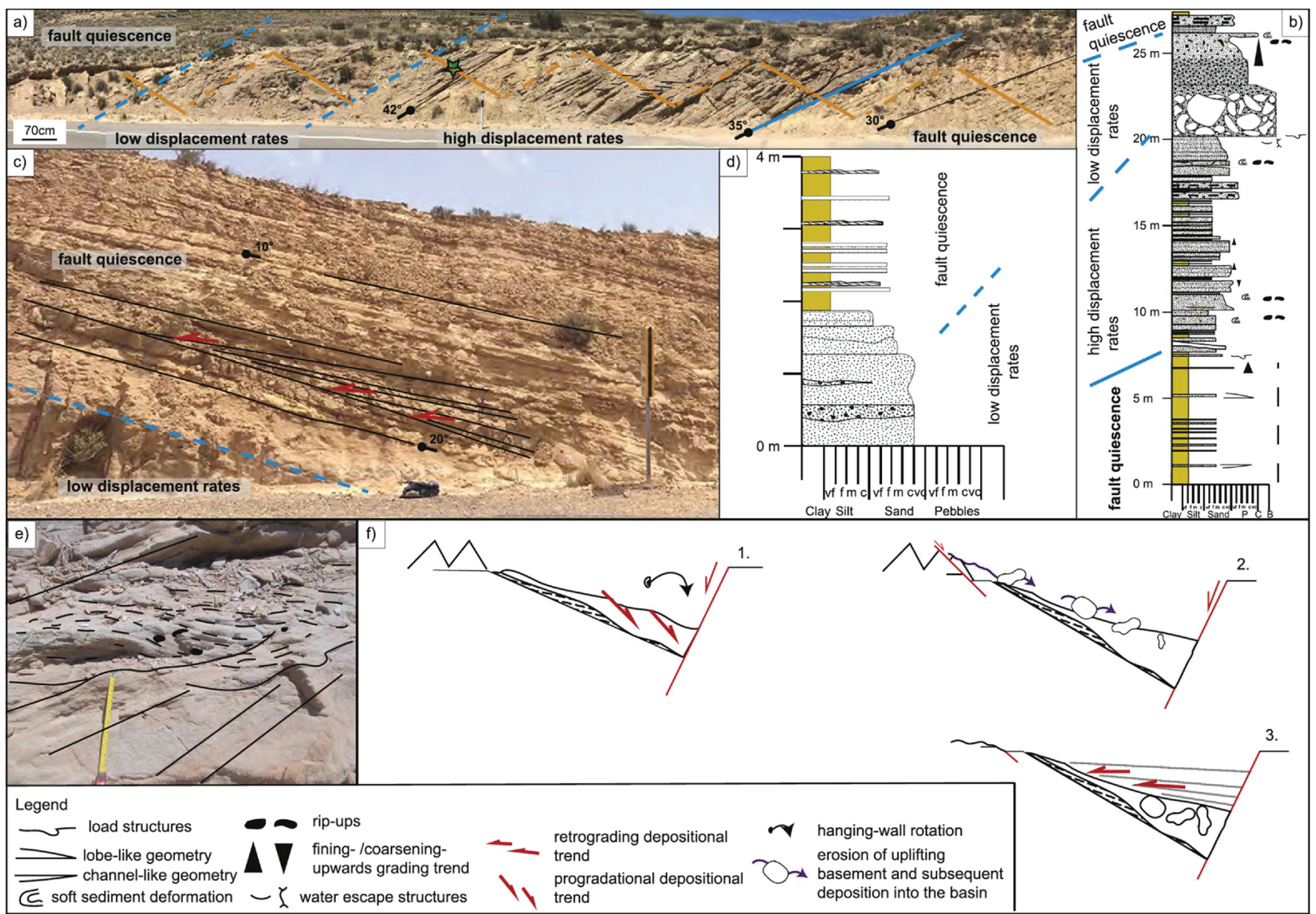

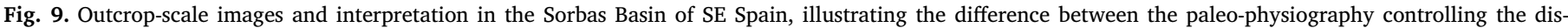

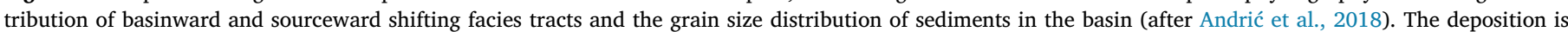

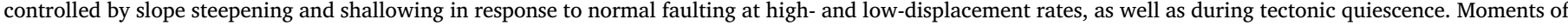

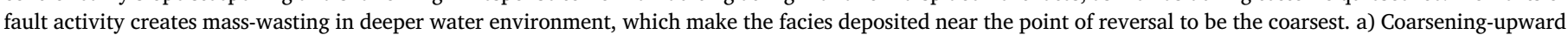

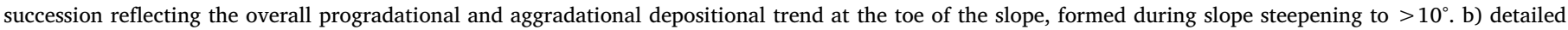

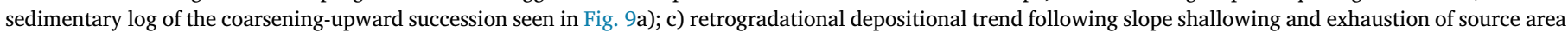

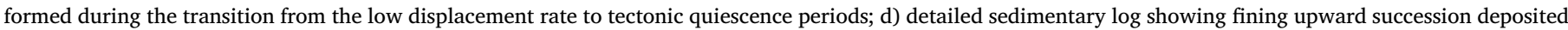

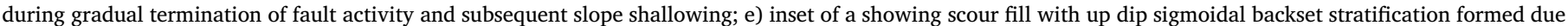

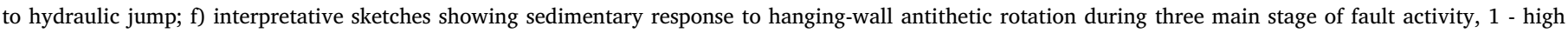
displacement rates; 2 - low displacement rates, and 3 - fault quiescence.

shelf storages (Fig. 9). In contrast, periods of fault quiescence are characterized by finer sedimentation in shallower environments, favoured by temporary storage on the shelf and a decreased input from sources area (Fig. 9).

\section{Discussion}

\subsection{Scales of tectonic successions}

The examples presented in this study exemplify the large spatial and temporal variability of tectonic successions observed from system of faults to individual movements along a single fault. These examples show that tectonic successions have spatial scales ranging from tens of metres to kilometres and temporal scales ranging from hundreds of thousands to million years. Furthermore, centimetres to metres synkinematic deposition responding to similar size faulting has been documented in many basins worldwide by outcrop studies (e.g., Andrić et al., 2018). However, movements along an individual fault or shear zone also include exhumation, which result in offsets much larger than the created depositional space. Such high offsets can reach tens of kilometres and have been observed along detachments associated with the formation of core-complexes or basalt decollements of thin-skinned thrust belts, where the accommodation space created in break-away, supra-detachment, foredeep or wedge-top basins is in the order of hundreds of metres to kilometres (e.g., Beaumont, 1981; Wernicke, 1985; Brun et al., 1994; Roure, 2008). The resulting change in bathymetry and topography created by exhumation are of similar order or magnitudes, locally controlled by climate and erodibility of rock types in the source area (e.g., Hooke and Rohrer, 1977; Willett et al., 2006; Flowers and Ehlers, 2018).

The conceptual model of tectonic successions presented here serves the practical need for quantifying the time and amplitude of tectonic movements in sedimentary basins. Plate tectonics megacycles open continental rifts that are buried beneath passive continental margins, which eventually become involved in oceanic subduction and subsequent continental collisions, leading to the formation of mountain chains. On this larger scale, the transition from continental sedimentation during the early stages of rifting to deep-water pelagic sedimentation later can be considered a large-scale sourceward-shifting facies tract, while the subsequent shallowing of sedimentary facies during subduction and collision is a large-scale basinward-shifting facies tract. Together, these facies tracts define a mega-tectonic (or first order) succession at the spatial and temporal scale of a plate tectonic cycle. Such mega-tectonic cycles can have very variable durations, spanning from 10 to $200 \mathrm{Myr}$, creating changes in topography/bathymetry in the order of 3-11 km (e.g., Dewey, 1988; Krapez, 1997; Audet 

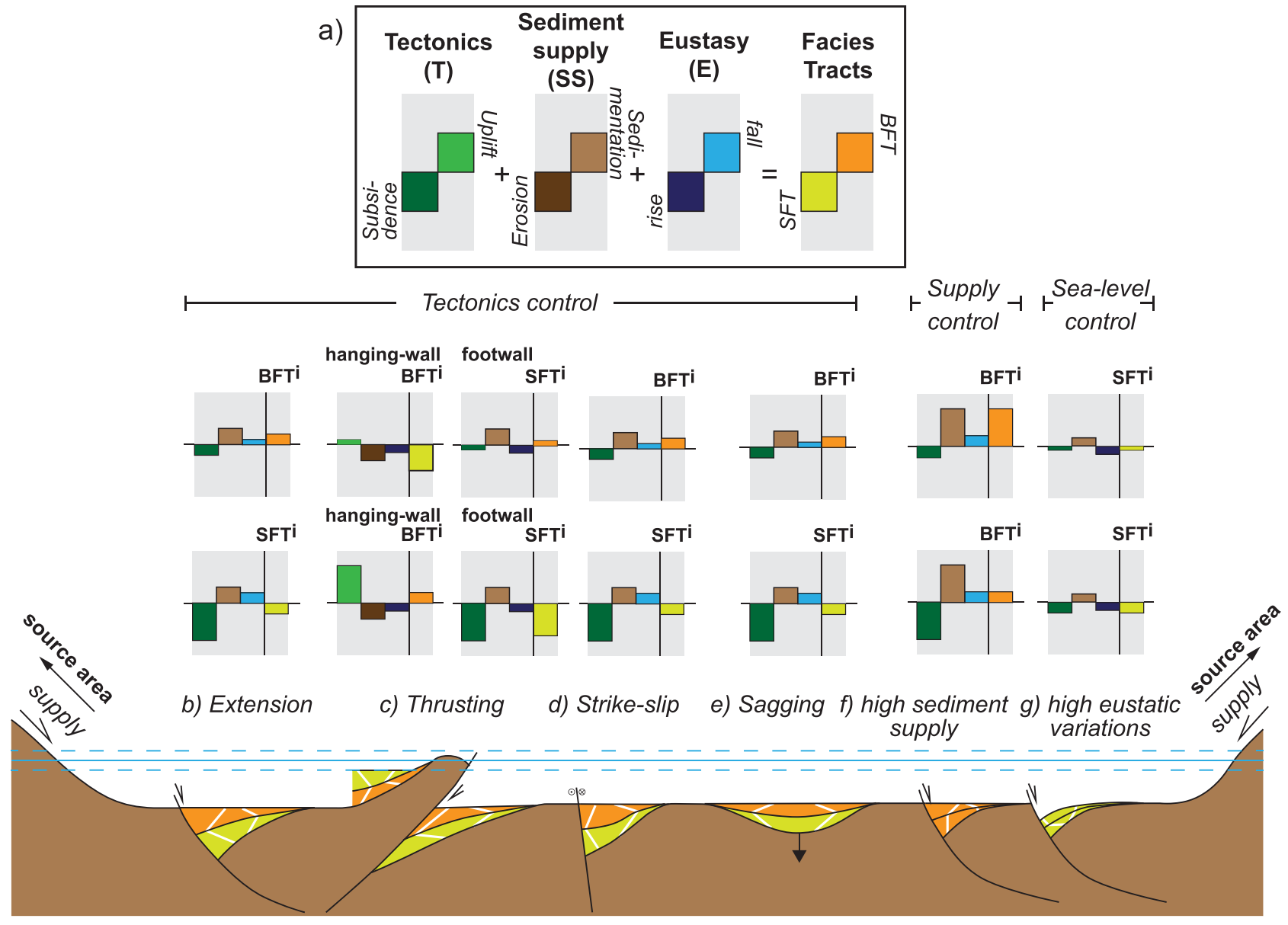

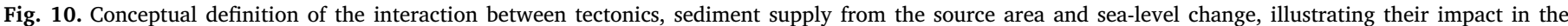

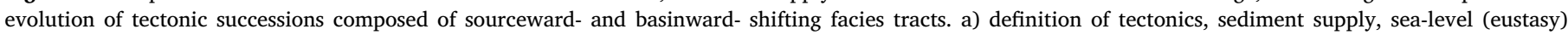

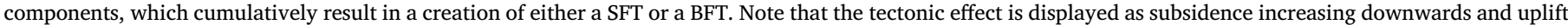

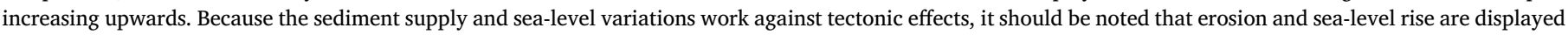

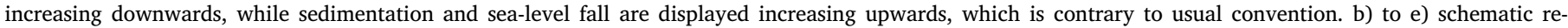

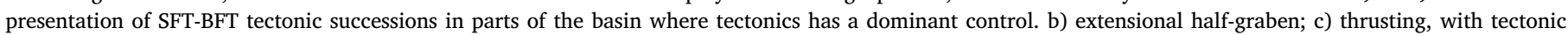

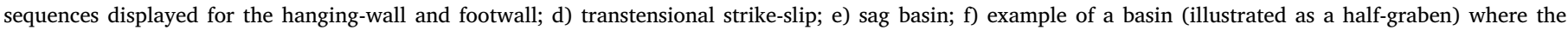

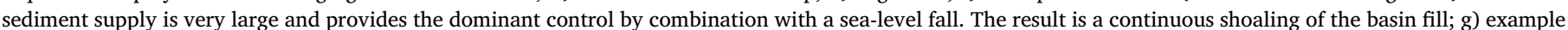

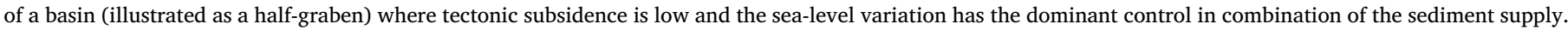
The result is continuous deepening of the basin. For a similar approach see also ter Borgh et al. (2015).

and Bürgmann, 2011).

The evolution of a sedimentary basin system as related to one of the various components of the Wilson cycle (such as continental rifts, subduction or continental collision) is commonly associated with the onset of sedimentation over a major unconformity, gradual deepening to the maximum paleodepth, which comprises a sourceward-shifting facies tract, followed by a gradual shoaling until the basin is completely filled, which defines a basinward-shifting facies tract. Examples of such basinal systems are provided by major extensional, contractional or strike-slip systems that exist within cratons or mountain chains, such as the East African Rift, the Pannonian Basin, South China Sea, or collisional systems where foreland basins contain a record of complete basin fill, such as the Northern Alpine or Carpathians forelands. These basin systems also show high variability in spatial and temporal scales. For instance, the evolution of a continental rift from onset to drifting (or abandonment) may last anywhere between 5-200 Myr, and create changes in topography/bathymetry in the order of $100 \mathrm{~m}$ to $10 \mathrm{~km}$ (Mosar et al., 2002; Ziegler and Cloetingh, 2004).

Sedimentary basin systems are composed of individual sub-basins, often formed diachronously, that may become connected (or sequestered) at a later stage due to migration of deformation centres or due to other mechanisms, such as thermal subsidence or tectonic inversion.
The associated sedimentation in these sub-basins involves an earlier facies deepening, comprising a sourceward-shifting facies tract, followed by a gradual shoaling when the rate of sediment supply surpasses the rate of creation of depositional space expressed as a basinwardshifting facies tract (such as TS ${ }^{\mathrm{i}}$ in Figs. 4, 6 and 7). Thus, the infill of an individual sub-basin may be described as a higher-order tectonic succession when compared with the whole sedimentary basin. The tectonic evolution of such sub-basins is time independent and may take anywhere between $0.5-60 \mathrm{Myr}$, creating changes in topography/bathymetry of $50 \mathrm{~m}$ to $8 \mathrm{~km}$.

Within the sub-basins, the activation of individual faults is responsible for the creation of depositional space at the local level and the formation of higher-order tectonic successions (e.g., the $\mathrm{TS}^{\mathrm{i}+1}$ cycles illustrated in Fig. 4b). Typical examples can be observed along growth faults observed in the North Sea and the Norwegian continental margin (Mosar et al., 2002) or syn-kinematic foredeep wedges observed in the Carpathians (Răbăgia et al., 2011). Their time scale may vary significantly, from $10 \mathrm{Kyr}$ to $20 \mathrm{Myr}$, creating changes in topography/ bathymetry of $10 \mathrm{~m}$ to $5 \mathrm{~km}$.

The total offset of a single fault surface is comprised of individual movements (or offsets) that take place during periods of faulting activity. Each individual offset may generate individual tectonic 


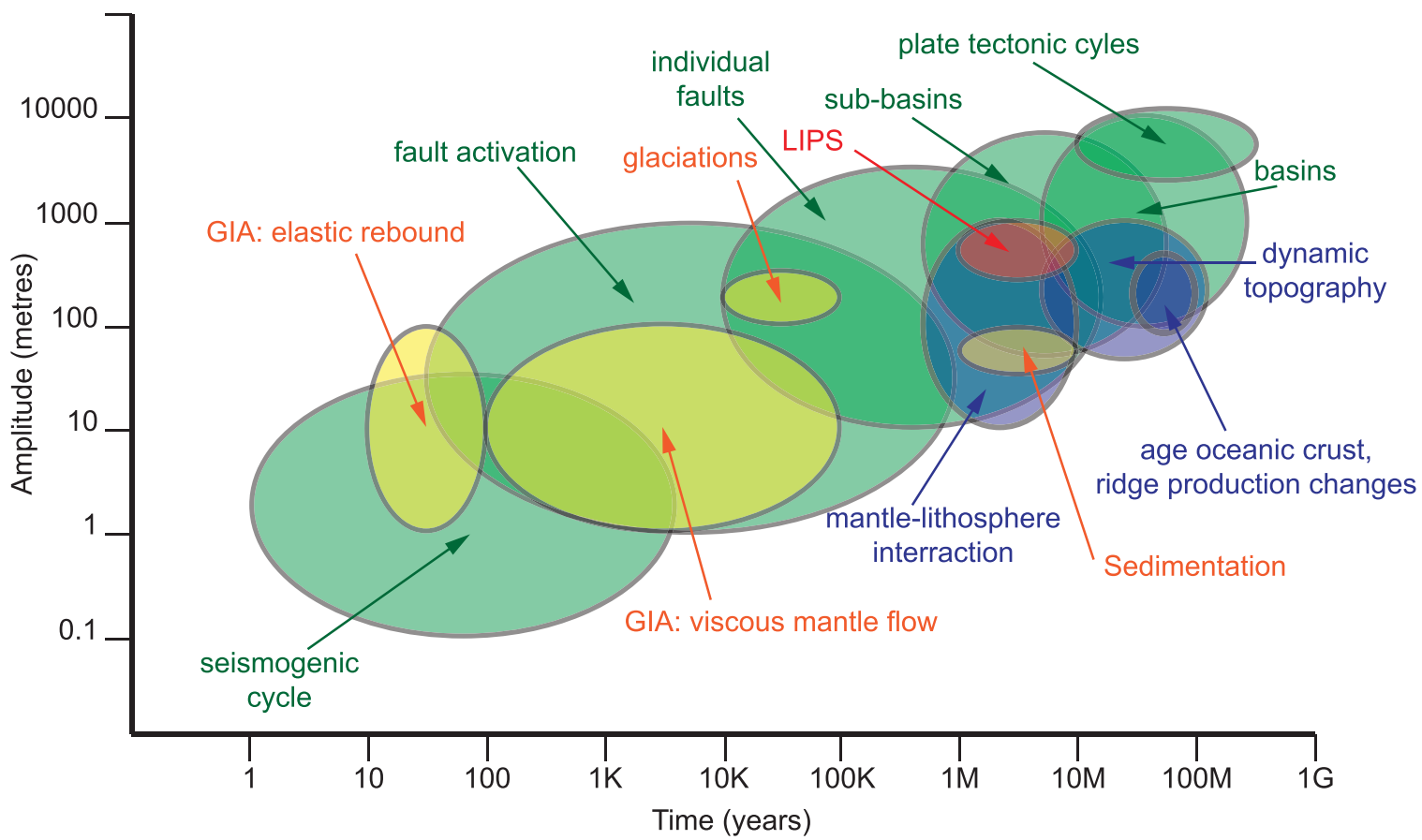

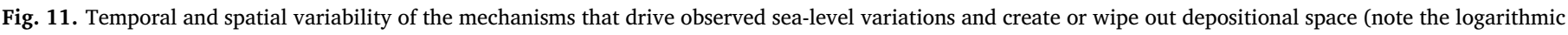

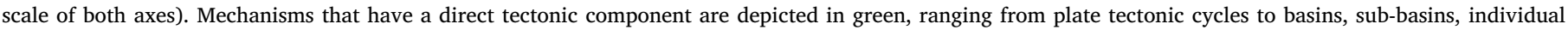

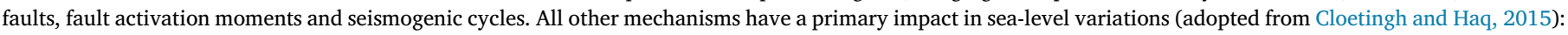

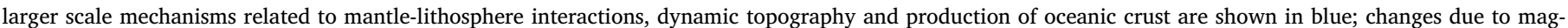

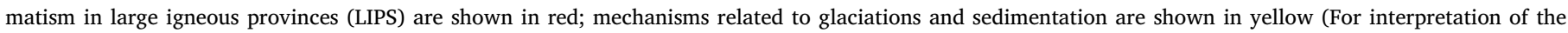
references to colour in this figure legend, the reader is referred to the web version of this article).

successions made up of SFT-BFT cycles (such as the higher-order cycles in Fig. 4a). These are higher-order cycles (when compared to the total offset along a fault), but their time scales again may vary significantly between about $30 \mathrm{yr}$ to $1 \mathrm{Myr}$, creating depositional space of $1 \mathrm{~m}-1000 \mathrm{~m}$. The tectonic signal can sometimes be interpreted in highresolution depositional cycles, such as in high frequency peritidal carbonate sedimentation (Bosence et al., 2009).

Even higher-orders of cyclicity than those defined by movements during fault activations occur (comprising individual SFT-BFT cycles) that can extend to as short time scales as the single seismogenic cycle, where mega-thrust earthquakes create surface offsets (and depositional space), reaching up to a few tens of meters that are subsequently filled with sediments at few years to thousands years' time scales. Examples are also available in the stratigraphic record, such as in the carbonate systems that are very sensitive to variations at the tidal scale (e.g., Cisne, 1986).

One may be tempted to classify such variable timescales of tectonic activity as "orders" of cyclicity, from first order major tectonic cycles to fifth or sixth order seismogenic cycles. However, such a strict classification is not necessary or practical, given the extreme temporal and spatial variability of tectonic movements. Therefore, we recommend that the order of periodicity is defined as a function of the relative scale being studied (i.e., at the level of the tectonic sedimentary cycle, system, basin, sub-basin or individual fault). By employing the most common observational techniques (seismic, well-log, and outcrop observations), only two levels of cyclicity of tectonic successions may therefore be commonly necessary in practice (a lower order " $i$ " and a higher order " $i+1$ "). For quantitatively defining the timing and amplitude of tectonic movements, the exact $i$ number is not relevant and may be left undefined.

\subsection{Factors controlling the geometry of tectonic successions}

In addition to tectonics, the evolution of sedimentary basins is influenced by other external forcing factors, such as the sediment supply, climate and sea-level variations that determine the resultant stratal architecture (Fig. 10a). In their initial formative stages, all basins are primarily controlled by tectonics. Whenever the rate of tectonic subsidence or uplift is greater than the cumulative rates of sediment supply and sea-level change, an alternation between SFTs and BFTs is observed, irrespective of whether tectonic activity is extensional, contractional, strike-slip or sagging due to sub-lithospheric processes (Fig. 10b-e). Extreme situations of very high sediment supply may work together with sea-level changes and tectonics, which may result in a situation where deepening of the facies is not observed at the onset of tectonics and the entire tectonic succession may contain only BFTs (Fig. 10f). The same result can be generated when a large sea-level fall, working together with the sediment supply, outpaces the creation of tectonic depositional space.

On the other extreme, the rate of tectonic subsidence may be very low, such as in the long-lived rift systems as in the Norwegian or North Sea margins, and surpassed by the combined effect of the sediment supply and sea-level variations resulting in tectonic successions entirely characterized by SFTs (Fig. 10g, e.g., Nottvedt et al., 1995). The same pattern of tectonic successions entirely characterized by SFTs during deformation times may be obtained when the sediment influx from the source area is trapped in intervening sub-basins, while structures situated at farther distances are characterized by condensed or starved sedimentation (e.g., Bartol et al., 2012; Munteanu et al., 2012; Matenco et al., 2016). This is also the case in post-tectonic times, when the basin is gradually filled and tectonic activity slows down considerably or ceases all together.

Sedimentary basins may acquire more "stable" depositional patterns later in their evolutionary history. This stability means unidirectional sediment flux largely controlled by the quasi-cyclic local/regional (eurybatic) and/or global (eustatic) sea-level variations, where sequence-stratigraphic approach and terminology can be applied more effectively for stratigraphic analyses. A good case in point is the North 
American Atlantic coast where earlier extensional stages of the breakup are buried under a later more typical passive-margin type sedimentation (e.g., Enachescu, 1992; Arantegui et al., 2019).

In summary, it can be stated that nearly all basins start off as being driven by tectonics and can later morph into stable platforms or passive margins when tectonic activity subsides or ceases. Thus, for a complete appreciation of the evolution of a large basin, both the tectonic-successions approach in the earlier history (recommended here) and the sequence-stratigraphic approach in the later stages may be required to unravel the complete sedimentological evolution of the basin.

\subsection{Variability of mechanisms controlling depositional space}

The temporal and spatial scales of mechanisms that drive sea-level variations and create or wipe out depositional space are extreme, ranging from years to hundreds of million years and from centimetres to tens of kilometres (Fig. 11). Therefore, understanding the impact of these mechanisms is essentially a multi-scale problem. The intrinsic lithospheric rheology, the rate of creation of depositional space and the dynamics of surface processes conditioned by climate and eustasy strongly influence the infill and physiography of sedimentary basins (Cloetingh and Haq, 2015). This infill is affected not only by modulating the rates of deformation, erosion and sediment supply, but also by the system's response to lithospheric flexure, rheology, thermal evolution, glacial isostatic adjustment, mantle-lithosphere interaction, rate of formation of oceanic lithosphere and dynamic topography (Fig. 11).

For instance, the extension rate, rheology and thermal convective or advective effects have direct impact in the width and structure of continental rifts, creating wide and shallow or narrow and deep structures (Burov and Cloetingh, 1997; Brun, 1999; van Wijk and Cloetingh, 2002; Huismans and Beaumont, 2003; Gueydan and Precigout, 2014; Naliboff et al., 2017). In such extensional zones thermal subsidence and the rate of sediment supply together modulate the timing and position of the point of reversal (POR, Fig. 2) between basinward- and sourceward- shifting facies tracts. During extension, the presence of inherited rheological weakness zones controls the evolution of asymmetric basins that migrate in space and with time (e.g., Manatschal et al., 2015; Balázs et al., 2017a). Crustal loads and rheology are modified by surface processes and sedimentation during extension, which influences the architecture and evolution of continental rifts (e.g., Burov and Cloetingh, 1997; Andrés-Martínez et al., 2019). The overall extension may be followed by the development of passive continental margins whose width is controlled by the initial rifting rates, rheology and structure (e.g., Mosar et al., 2002; Burov, 2007; Brune et al., 2014). Changes in climate significantly affect the balance between accretionary and erosional fluxes during convergence in orogens, resulting in changing the geometry and kinematics of associated basins (e.g., Willett and Brandon, 2002; Willett et al., 2006; Thiede and Ehlers, 2013; Armijo et al., 2015). Such external and internal controlling factors have been widely documented to impact the evolution of tectonic successions in various types of sedimentary basins (e.g., Buiter et al., 2009; Fillon et al., 2013; Erdos et al., 2014; Beniest et al., 2017, among others).

Mantle - lithosphere interaction is an important component that creates or destroys regional depositional space (Fig. 11), such as thermal subsidence in rift zones, which is particularly important for the evolution of passive continental margins (Steckler and Watts, 1978; Stephenson, 1989; Xie and Heller, 2009; Yamasaki and Stephenson, 2009; Cloetingh and Haq, 2015; Stein et al., 2018). Steps should also be taken to separate out the long-wavelength depositional space created or diminished by dynamic topography (i.e., by sub-lithospheric induced subsidence or uplift) that has regional effects on sedimentary basins (Fig. 11, Bertelloni and Gurnis, 1997; Flament et al., 2013) and also creates sourceward or basinward facies migration patterns that can be similar to those caused by sea-level changes.

In summary, the depositional space created or wiped out by tectonics may be higher than any other external or internal forcing factor and cannot be ignored at any spatial and temporal scale (Fig. 11). Therefore, the necessity of a tectonic successions' nomenclature serving the practical need for quantifying the time and amplitude of tectonic movements and deposition in sedimentary basins is very high.

\section{Conclusions}

Based on observations in tectonically-dominated environments, we have proposed a modified approach to understanding the forcing induced by fault movements in sedimentary systems. Tectonic activity, when reduced to its simplest expression, is the development of a single fault or subsidence episode, i.e., its activation, reactivation and duration that comprise its total history. Faults (or multiples thereof) produce basins that are filled with sediments. Thus, any starting point toward understanding the influence of tectonics in sedimentary successions has to be the history of the fault's kinematics (activation, increase or decrease in offset rate) and the response of sedimentary facies to these changes. Here we have endeavoured to produce a basic conceptual model of the facies response that can be applied at any scale of tectonic expression, from the movements along a single fault to the infilling at the basin-wide scale.

Our starting point is the conceptual definition of a tectonic succession (TS), bracketed by succession boundaries (SBs), and comprised of a sourceward-shifting facies tract (SFT) and a basinward-shifting facies tract (BFT), separated by a point of reversal (POR) and characterized by the balance between the rate of creation of depositional (accommodation) space ( $\delta \mathrm{AS})$ and the rate of sediment supply ( $\delta \mathrm{SS})$. In practice such tectonic successions are a function of the methodological resolution (seismic stratigraphy, well logs, outcrop studies) and have extremely variable temporal and spatial scales. This can range from the long temporal duration of the major tectonic cycles to moments of fault activation during megathrust earthquakes.

The conceptual tectonic successions model is applicable whether tectonics induce subsidence or uplift during deposition. Although these successions are more obvious in extensional systems, where many attempts at classifications are already available, we argue that the expression of basinward- and sourceward-shifting facies tracts is a unifying concept across all tectonic regimes and timescales and is, therefore, applicable in all practical situations. Their expression in terms of geometry, sedimentary facies and distribution can be extremely variable, controlled by the balance with other external or internal forcing factors, such as the variability of the sediment flux, eurybatic and eustatic variations, the basin morphology, slope stability and mass-wasting characteristics, or the autocyclic variations within the depositional system. But there is one common characteristic that makes the definition of these BFTs and SFTs possible: the paleo-physiographic position in the depositional environment and its variability with time.

\section{Declaration of Competing Interest}

The authors declare that they have no known competing financial interests or personal relationships that could have appeared to influence the work reported in this paper.

The authors declare the following financial interests/personal relationships which may be considered as potential competing interests.

\section{Acknowledgements}

The authors express their thanks to Attila Balázs, Harry Doust, John Milliman, Cornel Olariu and Luis Pomar for their reviews of an early version of the paper. We acknowledge our discussions with Ron Steel on the need for a distinctive terminology for tectonic successions. The suggestions from the editor and two anonymous reviewers have significantly improved the quality of the original manuscript. 


\section{References}

Alexander, J., Leeder, M., 1987. Active tectonic control on alluvial architecture. In: In: Ethridge, F.G., Flores, R.M., Harvey, M.D. (Eds.), Recent Developments in Fluvial Sedimentology, vol. 39. SEPM Soc. Sediment. Geol. Spec. Publ., pp. 243-252.

Allen, P.A., Homewood, P., Williams, G.D., 1986. Foreland basins: an introduction. In: In: Allen, P.A., Homewood, P. (Eds.), Foreland Basins. Spec. Publs. Int. Ass. Sediment 8. Blackwell Scientific Publications, Oxford, pp. 3-14.

Alves, T.M., Cupkovic, T., 2018. Footwall degradation styles and associated sedimentary facies distribution in SE Crete: insights into tilt-block extensional basins on continental margins. Sediment. Geol. 367, 1-19.

Andrés-Martínez, M., Pérez-Gussinyé, M., Armitage, J., Morgan, J.P., 2019. Thermomechanical implications of sediment transport for the architecture and evolution of continental rifts and margins. Tectonics 38, 641-665.

Andrić, N., Sant, K., Matenco, L., Mandic, O., Tomljenović, B., Pavelić, D., Hrvatović, H., Demir, V., Ooms, J., 2017. The link between tectonics and sedimentation in asymmetric extensional basins: inferences from the study of the Sarajevo-Zenica basin. Mar. Petrol. Geol. 83, 305-332.

Andrić, N., Matenco, L., Hilgen, F., de Bresser, H., 2018. Structural controls on sedimentation during asymmetric extension: the case of Sorbas Basin (SE Spain). Global Planet. Change 171, 185-206.

Angelier, J., Colletta, B., 1983. Tension fractures and extensional tectonics. Nature 301, 49-51.

Arantegui, A., Jerrett, R., Schröder, S., Bulot, L.G., Gatto, R., Monari, S., Redfern, J., 2019. Constraining Mesozoic early post-rift depositional systems evolution along the eastern Central Atlantic margin. Sediment. Geol. 386, 31-51.

Armijo, R., Lacassin, R., Coudurier-Curveur, A., Carrizo, D., 2015. Coupled tectonic evolution of Andean orogeny and global climate. Earth-Sci. Rev. 143, 1-35.

Audet, P., Bürgmann, R., 2011. Dominant role of tectonic inheritance in supercontinent cycles. Nat. Geosci. 4, 184-187.

Balázs, A., Burov, E., Matenco, L., Vogt, K., Francois, T., Cloetingh, S., 2017Ea. Symmetry during the syn- and post-rift evolution of extensional back-arc basins: the role of inherited orogenic structures. Earth Planet. Sci. Lett. 462, 86-98.

Balázs, A., Granjeon, D., Matenco, L., Sztanó, O., Cloetingh, S., 2017Eb. Tectonic and climatic controls on asymmetric half-graben sedimentation: inferences from 3-D numerical modeling. Tectonics 36, 2123-2141.

Balázs, A., Magyar, I., Matenco, L., Sztanó, O., Tókés, L., Horváth, F., 2018. Morphology of a large paleo-lake: analysis of compaction in the Miocene-Quaternary Pannonian Basin. Global Planet. Change 171, 134-147.

Balázs, A., Matenco, L., Magyar, I., Horváth, F., Cloetingh, S., 2016. The link between tectonics and sedimentation in back-arc basins: new genetic constraints from the analysis of the Pannonian Basin. Tectonics 35, 1526-1559.

Ballato, P., Brune, S., Strecker, M.R., 2019. Sedimentary loading-unloading cycles and faulting in intermontane basins: insights from numerical modeling and field observations in the NW Argentine Andes. Earth Planet. Sci. Lett. 506, 388-396.

Ballato, P., Nowaczyk, N.R., Landgraf, A., Strecker, M.R., Friedrich, A., Tabatabaei, S.H., 2008. Tectonic control on sedimentary facies pattern and sediment accumulation rates in the Miocene foreland basin of the southern Alborz mountains, northern Iran. Tectonics 27https://doi.org/10.1029/2008TC002278. TC6001.

Barnes, P.M., Sutherland, R., Delteil, J., 2005. Strike-slip structure and sedimentary basins of the southern Alpine Fault, Fiordland, New Zealand. GSA Bull. 117, 411-435.

Barrett, B.J., Hodgson, D.M., Collier, R.E.L., Dorrell, R.M., 2018. Novel 3D sequence stratigraphic numerical model for syn-rift basins: analysing architectural responses to eustasy, sedimentation and tectonics. Mar. Petrol. Geol. 92, 270-284.

Bartol, J., Matenco, L., Garcia-Castellanos, D., Leever, K., 2012. Modelling depositional shifts between sedimentary basins: sediment pathways in Paratethys basins during the Messinian Salinity Crisis. Tectonophysics 536-537, 110-121.

Beaumont, C., 1981. Foreland basins. Geophys. J. R. Astronon. Soc. 65, 291-329.

Beniest, A., Koptev, A., Burov, E., 2017. Numerical models for continental break-up: implications for the South Atlantic. Earth Planet. Sci. Lett. 461, 176-189.

Bertelloni, C.L., Gurnis, M., 1997. Cenozoic subsidence and uplift of continents from timevarying dynamic topography. Geology 25, 735-738.

Bosence, D., 2005. A genetic classification of carbonate platforms based on their basinal and tectonic settings in the Cenozoic. Sediment. Geol. 175, 49-72.

Bosence, D., Procter, E., Aurell, M., Bel Kahla, A., Boudagher-Fadel, M., Casaglia, F., Cirilli, S., Mehdie, M., Nieto, L., Rey, J., Scherreiks, R., Soussi, M., Waltham, D., 2009. A dominant tectonic signal in high-frequency, peritidal carbonate cycles? A regional analysis of Liassic platforms from Western Tethys. J. Sediment. Res. A Sediment. Petrol. Process. 79, 389-415.

Brown Jr, L.F., Fisher, W.L., 1977. Seismic-stratigraphic interpretation of depositional systems: examples from Brazilian rift and pull-apart basins. In: In: Payton, C.E. (Ed.), Seismic Stratigraphy - Applications to Hydrocarbon Exploration. American Association of Petroleum Geologists Memoir 26. AAPG Memoir, pp. 213-248.

Bruhn, R., Steel, R., 2003. High-resolution sequence stratigraphy of a clastic foredeep succession (Paleocene, Spitsbergen): an example of peripheral-bulge-controlled depositional architecture. J. Sediment. Res. 73, 745-755.

Brun, J.-P., Sokoutis, D., Van Den Driessche, J., 1994. Analogue modeling of detachment fault systems and core complexes. Geology 22, 319-322.

Brun, J.P., 1999. Narrow rifts versus wide rifts: inferences for the mechanics of rifting from laboratory experiments. Philos. Trans. R. Soc. Lond. Ser. A Math. Phys. Sci. 357, 695-712.

Brune, S., Heine, C., Perez-Gussinye, M., Sobolev, S.V., 2014. Rift migration explains continental margin asymmetry and crustal hyper-extension. Nat. Commun. 5, 4014. https://doi.org/10.1038/ncomms5014.

Buck, W.R., 1991. Modes of continental lithospheric extension. J. Geophys. Res. 96,
20161-20178.

Buck, W.R., 2015. The dynamics of continental breakup and extension. In: Schubert, G. (Ed.), Treatise on Geophysics, second edition. Elsevier, Oxford, pp. 325-379.

Buiter, S.J.H., Pfiffner, O.A., Beaumont, C., 2009. Inversion of extensional sedimentary basins: a numerical evaluation of the localisation of shortening. Earth Planet. Sci. Lett. 288, 492-504.

Burns, B.A., Heller, P.L., Marzo, M., Paola, C., 1997. Fluvial response in a sequence stratigraphic framework; example from the Montserrat fan delta, Spain. J. Sediment. Res. A Sediment. Petrol. Process. 67, 311-321.

Burov, E., 2007. The role of gravitational instabilities, density structure and extension rate in the evolution of continental margins. Geol. Soc. Lond. Spec. Publ. 282, $139-156$.

Burov, E., Cloetingh, S., 1997. Erosion and rift dynamics: new thermomechanical aspects of post-rift evolution of extensional basins. Earth Planet. Sci. Lett. 150, 7-26.

Burov, E., Gerya, T., 2014. Asymmetric three-dimensional topography over mantle plumes. Nature 513, 85-89.

Burov, E.B., Diament, M., 1992. Flexure of the continental lithosphere with multilayered lithosphere. Geophys. J. Int. 109, 449-468.

Catuneanu, O., 2004. Retroarc foreland systems - evolution through time. J. Afr. Earth Sci. 38, 225-242.

Catuneanu, O., 2019. Scale in sequence stratigraphy. Mar. Petrol. Geol. 106, 128-159.

Catuneanu, O., Abreu, V., Bhattacharya, J.P., Blum, M.D., Dalrymple, R.W., Eriksson, P.G., Fielding, C.R., Fisher, W.L., Galloway, W.E., Gibling, M.R., Giles, K.A., Holbrook, J.M., Jordan, R., Kendall, C.G.S.C., Macurda, B., Martinsen, O.J., Miall, A.D., Neal, J.E., Nummedal, D., Pomar, L., Posamentier, H.W., Pratt, B.R., Sarg, J.F., Shanley, K.W., Steel, R.J., Strasser, A., Tucker, M.E., Winker, C., 2009. Towards the standardization of sequence stratigraphy. Earth-Sci. Rev. 92, 1-33.

Chorowicz, J., 2005. The East African rift system. J. Afr. Earth Sci. 43, 379-410.

Christie-Blick, N., Biddle, K.T., 1985. Deformation and basin formation along strike-slip faults. SEPM Soc. Sediment. Geol. Spec. Publ. 37, 1-34.

Cisne, J.L., 1986. Earthquakes recorded stratigraphically on carbonate platforms. Nature 323, 320-322.

Clevis, Q., De Boer, P.L., Nijman, W., 2004. Differentiating the effect of episodic tectonism and Eustatic sea-level fluctuations in foreland basins filled by alluvial fans and axial deltaic systems: insights from a three-dimensional stratigraphic forward model. Sedimentology 51, 809-835.

Cloetingh, S., Burov, E., Matenco, L., Beekman, F., Roure, F., Ziegler, P.A., 2013. The Moho in extensional tectonic settings: insights from thermo-mechanical models. Tectonophysics 609, 558-604.

Cloetingh, S., Haq, B.U., 2015. Inherited landscapes and sea level change. Science 347.

Cloetingh, S., Ziegler, P.A., Beekman, F., Burov, E.B., Garcia-Castellanos, D., Matenco, L. 2015. Tectonic models for the evolution of sedimentary basins. In: Schubert, G. (Ed.), Treatise on Geophysics, second edition. Elsevier, Oxford, pp. 513-592.

Cloetingh, S.A.P.L., Ziegler, P.A., Bogaard, P.J.F., Andriessen, P.A.M., Artemieva, I.M., Bada, G., van Balen, R.T., Beekman, F., Ben-Avraham, Z., Brun, J.P., Bunge, H.P., Burov, E.B., Carbonell, R., Facenna, C., Friedrich, A., Gallart, J., Green, A.G., Heidbach, O., Jones, A.G., Matenco, L., Mosar, J., Oncken, O., Pascal, C., Peters, G., Sliaupa, S., Soesoo, A., Spakman, W., Stephenson, R.A., Thybo, H., Torsvik, T., de Vicente, G., Wenzel, F., Wortel, M.J.R., 2007. TOPO-EUROPE: The geoscience of coupled deep Earth-surface processes. Global Planet. Change 58, 1-118.

Comas, M.C., Garcia-Duenas, V., Jurado, M.J., 1992. Neogene extensional tectonic evolution of the Alboran Basin from MCS data. Geomarine Lett. 12-24.

Corti, G., 2008. Control of rift obliquity on the evolution and segmentation of the main Ethiopian rift. Nat. Geosci. 1, 258-262.

Corti, G., 2009. Continental rift evolution: from rift initiation to incipient break-up in the Main Ethiopian Rift, East Africa. Earth-Sci. Rev. 96, 1-53.

Covault, J.A., Hubbard, S.M., Graham, S.A., Hinsch, R., Linzer, H.-G., 2009. Turbiditereservoir architecture in complex foredeep-margin and wedge-top depocenters, Tertiary Molasse foreland basin system. Aust. Mar. Petrol. Geol. 26, 379-396.

Cross, N.E., Bosence, D.W.J., 2008. Tectono-sedimentary models for rift-Basin carbonate systems. In: Lukasik, J., Simo, J.A. (Eds.), Controls on Carbonate Platform and Reef Development. SEPM Soc. Sediment. Geol. Spec. Publ, pp. 83-105.

Csato, I., Kendall, C.G.S.C., 2002. Modeling of stratigraphic architectural patterns in extensional settings-towards a conceptual model. Comput. Geosci. 28, 351-356.

Dahlstrom, C.D.A., 1970. Structural geology in the eastern margin of the Canadian Rocky Mountains. Bull. Can. Pet. Geol. 18, 332-406.

DeCelles, P.G., Ducea, M.N., Kapp, P., Zandt, G., 2009. Cyclicity in Cordilleran orogenic systems. Nat. Geosci. 2, 251-257.

DeCelles, P.G., Giles, K.A., 1996. Foreland basin systems. Basin Res. 8, 105-123.

DeCelles, P.G., Gray, M.B., Ridgway, K.D., Cole, R.B., Srivastava, P., Pequera, N., Pivnik, D.A., 1991. Kinematic history of a foreland uplift from Paleocene synorogenic conglomerate, Beartooth range, Wyoming and Montana. Geol. Soc. Am. Bull. 103, 1458-1475.

DeCelles, P.G., Kapp, P., Gehrels, G.E., Ding, L., 2014. Paleocene-Eocene foreland basin evolution in the Himalaya of southern Tibet and Nepal: implications for the age of initial India-Asia collision. Tectonics 33, 824-849.

Desegaulx, P., Moretti, I., 1988. Subsidence history of the Ebro Basin. J. Geodyn. 10, 9-24.

Dewey, J.F., 1988. Lithospheric stress, deformation, and tectonic cycles: the disruption of Pangaea and the closure of Tethys. Geol. Soc. Lond. Spec. Publ. 37, 23.

Plate tectonics and sedimentation. In: In: Dickinson, W.R. (Ed.), Tectonics and Sedimentation 22. SEPM Soc. Sediment. Geol. Spec. Publ., Tulsa, Oklohoma, pp. $1-27$.

Do Couto, D., Gorini, C., Jolivet, L., Lebret, N., Augier, R., Gumiaux, C., d'Acremont, E., Ammar, A., Jabour, H., Auxietre, J.-L., 2016. Tectonic and stratigraphic evolution of the Western Alboran Sea Basin in the last 25 Myrs. Tectonophysics 677-678, 
280-311.

Do Couto, D., Gumiaux, C., Augier, R., Lebret, N., Folcher, N., Jouannic, G., Jolivet, L., Suc, J.-P., Gorini, C., 2014. Tectonic inversion of an asymmetric graben: insights from a combined field and gravity survey in the Sorbas basin. Tectonics 33, 1360-1385.

Dondurur, D., Küçük, H.M., Çifçi, G., 2013. Quaternary mass wasting on the western Black Sea margin, offshore of Amasra. Global Planet. Change 103, 248-260.

Einsele, G., 2000. Sedimentary Basins: Evolution, Facies and Sediment Budget, second edition. Springer $792 \mathrm{pp}$.

Embry, A.F., 1990. A tectonic origin for third order depositional sequences in extensional basins - implications for basin modelling. In: Cross, T.A. (Ed.), Quantitative Dynamic Stratigraphy. Prentice Hall, New York, pp. 491-501.

Embry, A.F., 2002. Transgressive-regressive (T-R) sequence stratigraphy. In: Armentrout, J.M., Rosen, N.C. (Eds.), Sequence Stratigraphic Models for Exploration and Production: Evolving Methodology, Emerging Models and Application Histories. SEPM Soc. Sediment. Geol. Spec. Publ., pp. 151-172.

Enachescu, M.E., 1992. Enigmatic basin offshore Newfoundland. Can. J. Explor. Geophys. 28, 44-61.

Erdos, Z., Huismans, R.S., van der Beek, P., Thieulot, C., 2014. Extensional inheritance and surface processes as controlling factors of mountain belt structure. J. Geophys. Res. - Solid Earth 119, 9042-9061.

Ershov, A.V., Brunet, M.-F., Korotaev, M.V., Nikishin, A.M., Bolotov, N., 1999. Late Cenozoic burial history and dynamics of the Northern Caucasus molasse basin: implications for foreland basin modelling. Tectonophysics 313, 219-241.

Faccenna, C., Becker, T.W., Auer, L., Billi, A., Boschi, L., Brun, J.P., Capitanio, F.A., Funiciello, F., Horvàth, F., Jolivet, L., Piromallo, C., Royden, L., Rossetti, F., Serpelloni, E., 2014. Mantle dynamics in the Mediterranean. Rev. Geophys. 52, 283-332.

Faccenna, C., Becker, T.W., Conrad, C.P., Husson, L., 2013. Mountain building and mantle dynamics. Tectonics $32,1-15$.

Fillon, C., Huismans, R.S., van der Beek, P., Munoz, J.A., 2013. Syntectonic sedimentation controls on the evolution of the southern Pyrenean fold-and-thrust belt: inferences from coupled tectonic-surface processes models. J. Geophys. Res. - Solid Earth 118, 5665-5680.

Flament, N., Gurnis, M., Müller, R.D., 2013. A review of observations and models of dynamic topography. Lithosphere 5, 189-210.

Flowers, R.M., Ehlers, T.A., 2018. Rock erodibility and the interpretation of low-temperature thermochronologic data. Earth Planet. Sci. Lett. 482, 312-323.

Fongngern, R., Olariu, C., Steel, R.J., Krézsek, C., 2016. Clinoform growth in a Miocene, Para-tethyan deep lake basin: thin Topsets, irregular Foresets and thick Bottomsets. Basin Res. 28, 770-795.

Ford, M., 2004. Depositional wedge tops: interaction between low basal friction external orogenic wedges and flexural foreland basins. Basin Res. 16, 361-375.

Frostick, L.E., Steel, R.J., 1993. Tectonic signatures in sedimentary basin fills: an overview. Spec. Publ. Int. Assoc. Sediment. 20, 1-9.

Fuller, C.W., Willett, S.D., Brandon, M.T., 2006. Formation of forearc basins and their influence on subduction zone earthquakes. Geology 34, 65-68.

Galloway, W.E., 1986. Growth Faults and Fault-Related Structures of Prograding Terrigenous Clastic Continental Margins. Gulf Coast Association of Geological Societies Transactions, pp. 36 .

Garcia-Castellanos, D., 2002. Interplay between lithospheric flexure and river transport in foreland basins. Basin Res. 14, 89-104.

Garcia-Castellanos, D., 2006. Long-term evolution of tectonic lakes: climatic controls on the development of internally drained basins. Geol. Soc. Am. Special Pap. 398 283-294.

Garcia-Castellanos, D., Cloetingh, S., 2011. Modeling the interaction between lithospheric and surface processes in foreland basins. In: Busby, C., Azor, A. (Eds.), Tectonics of Sedimentary Basins. Wiley Online Books, pp. 152-181.

Gawthorpe, R.L., Fraser, A.J., Collier, R.E.L., 1994. Sequence stratigraphy in active extensional basins: implications for the interpretation of ancient basin-fills. Mar. Petrol. Geol. 11, 642-658.

Gawthorpe, R.L., Leeder, M.R., 2000. Tectono-sedimentary evolution of active extensional basins. Basin Res. 12, 195-218.

Gómez-Paccard, M., López-Blanco, M., Costa, E., Garcés, M., Beamud, E., Larrasoaña, J.C., 2012. Tectonic and climatic controls on the sequential arrangement of an alluvial fan/fan-delta complex (Montserrat, Eocene, Ebro Basin, NE Spain). Basin Res. 24, $437-455$.

Grool, A.R., Ford, M., Vergés, J., Huismans, R.S., Christophoul, F., Dielforder, A., 2018 Insights into the crustal-scale dynamics of a doubly Vergent Orogen from a quantitative analysis of its forelands: a case study of the Eastern Pyrenees. Tectonics 37, 450-476.

Gueydan, F., Precigout, J., 2014. Modes of continental rifting as a function of ductile strain localization in the lithospheric mantle. Tectonophysics 612, 18-25.

Güneş, P., Aksu, A.E., Hall, J., 2018. Structural framework and deformation history of the western Cyprus Arc. Tectonophysics 744, 438-457.

Gurnis, M., 1993. Phanerozoic marine inundation of continents driven by dynamic topography above Subducting slabs. Nature 364, 589.

Haq, B., Hardenbol, J., Vail, P., 1987. Chronology of fluctuating sea level since Triassic (250 million years to present). Science $235,1156-1167$

Haq, B.U., 2014. Cretaceous eustasy revisited. Global Planet. Change 113, 44-58.

Hardenbol, J., Thierry, J., Farley, M.B., Jacquin, T., Graciansky, P.-C., Vail, P.R., 1999. Mesozoic and cenozoic sequence chronostratigraphic framework of European basins. In: In: Graciansky, P.-C., Hardenbol, J., Jacquin, T., Vail, P.R. (Eds.), Mesozoic and Cenozoic Sequence Stratigraphy of European Basins, vol 60. SEPM Soc. Sediment. Geol. Spec. Publ, pp. 12-67.

Haughton, P., 2001. Contained turbidites used to track sea bed deformation and basin migration, Sorbas Basin, south-east Spain. Basin Res, 13, 117-139.
Hawie, N., Deschamps, R., Granjeon, D., Nader, F.H., Gorini, C., Müller, C., Montadert, L., Baudin, F., 2017. Multi-scale constraints of sediment source to sink systems in frontier basins: a forward stratigraphic modelling case study of the Levant region. Basin Res. 29, 418-445.

Heller, P.L., Angevine, C.L., Winslow, N.S., Paola, C., 1988. Two-phase stratigraphic model of foreland-basin sequences. Geology 16, 501-504.

Henstra, G.A., Grundvåg, S.-A., Johannessen, E.P., Kristensen, T.B., Midtkandal, I., Nystuen, J.P., Rotevatn, A., Surlyk, F., Sæther, T., Windelstad, J., 2016. Depositional processes and stratigraphic architecture within a coarse-grained rift-margin Turbidite system: the Wollaston Forland Group, east Greenland. Mar. Petrol. Geol. 76, 187-209.

Heron, P.J., Pysklywec, R.N., Stephenson, R., 2016. Lasting mantle scars lead to perennial plate tectonics. Nat. Commun 7, 11834. https://doi.org/10.1038/ncomms11834.

Hinsken, S., Ustaszewski, K., Wetzel, A., 2007. Graben width controlling syn-rift sedimentation: the Palaeogene southern Upper Rhine Graben as an example. Int. J. Earth Sci. 96, 979-1002.

Hodgson, D.M., Haughton, P.D.W., 2004. Impact of synsedimentary faulting on gravity current behaviour and deep-water stratigraphy: Tabernas-Sorbas Basin, SE Spain. In: In: Lomas, A.S., Joseph, P. (Eds.), Confined Turbidite Systems. Geol. Soc. London Spec. Publ., vol 222. pp. 135-158.

Homewood, P., Allen, P.A., Williams, G.D., 1986. Dynamics of the Molasse basin of western Switzerland. In: In: Allen, P.A., Homewood, P. (Eds.), Foreland Basins. Spec. Publ. Int. Ass. Sed. 8. Blackwell Scientific Publications, Oxford, pp. 199-218.

Hooke, R.L., Rohrer, W.L., 1977. Relative erodibility of source-area Rock Types, as determined from 2nd-order variations in Alluvial-Fan size. GSA Bulletin 88, 1177-1182.

Horton, B.K., 2018. Sedimentary record of Andean mountain building. Earth-Sci. Rev. 178, 279-309.

Horváth, F., Bada, G., Szafian, P., Tari, G., Adam, A., Cloetingh, S., 2006. Formation and deformation of the Pannonian Basin: constraints from observational data. Geol. Soc. Lond. Memoirs 32, 191-206.

Horváth, F., Musitz, B., Balázs, A., Végh, A., Uhrin, A., Nádor, A., Koroknai, B., Pap, N., Tóth, T., Wórum, G., 2015. Evolution of the Pannonian basin and its geothermal resources. Geothermics 53, 328-352.

Horváth, F., Royden, L., 1981. Mechanism for the formation of the intra-carpathian basins: a review. Earth Evol. Sci. 3-4, 307-316.

Huismans, R.S., Beaumont, C., 2003. Symmetric and asymmetric lithospheric extension: relative effects of frictional-plastic and viscous strain softening. J. Geophys. Res. Solid Earth 108, 2496

Jervey, M.T., et al., 1988. Quantitative geological modelling of siliciclastic rock sequences and their seismic expression. In: In: Wilgus, C.K. (Ed.), Sea-level Changes-An Integrated Approach 42. SEPM Special Publication. Soc. Econom. Paleontol. Mineral, Tulsa, pp. 47-69.

Jolivet, L., Faccenna, C., Huet, B., Labrousse, L., Le Pourhiet, L., Lacombe, O., Lecomte, E. Burov, E., Denèle, Y., Brun, J.-P., Philippon, M., Paul, A., Salaün, G., Karabulut, H., Piromallo, C., Monié, P., Gueydan, F., Okay, A.I., Oberhänsli, R., Pourteau, A., Augier, R., Gadenne, L., Driussi, O., 2013. Aegean tectonics: Strain localisation, slab tearing and trench retreat. Tectonophysics 597-598, 1-33.

Jordan, T.E., Flemings, P.B., Beer, J.A., 1988. Dating thrust fault activity by use of foreland basin strata. In: Kleinspehn, K.L., Paola, C. (Eds.), New Perspectives in Basin Analyses. Springer, New York, pp. 308-330.

Knierzinger, W., Wagreich, M., Palzer-Khomenko, M., Gier, S., Meszar, M., Lee, E.Y. Koukal, V., Strauss, P., 2018. Provenance and palaeogeographic evolution of Lower Miocene sediments in the eastern North Alpine Foreland Basin. Swiss J. Geosci. https://doi.org/10.1007/s00015-018-0312-9.

Kooi, H., Cloetingh, S., Burrus, J., 1992. Lithospheric necking and regional isostasy at extensional basins, 1, Subsidence and gravity modelling with an application to the Gulf of Lions Margin (SE France). J. Geophys. Res. 97, 17553-17572.

Krapez, B., 1997. Sequence-stratigraphic concepts applied to the identification of depositional basins and global tectonic cycles. Aust. J. Earth Sci. 44, 1-36.

Krézsek, C., Bally, A.W., 2006. The Transylvanian Basin (Romania) and its relation to the Carpathian fold and thrust belt: insights in gravitational salt tectonics. Mar. Petrol. Geol. 23, 405-442.

Krézsek, C., Filipescu, S., Silye, L., Matenco, L., Doust, H., 2010. Miocene facies associations and sedimentary evolution of the Southern Transylvanian Basin (Romania) implications for hydrocarbon exploration. Mar. Petrol. Geol. 27, 191-214.

Krézsek, C., Lăpădat, A., Maţenco, L., Arnberger, K., Barbu, V., Olaru, R., 2013. Strain partitioning at orogenic contacts during rotation, strike-slip and oblique convergence: paleogene-early Miocene evolution of the contact between the South Carpathians and Moesia. Global Planet. Change 103, 63-81.

Krijgsman, W., Fortuin, A.R., Hilgen, F.J., Sierro, F.J., 2001. Astrochronology for the Messinian Sorbas basin (SE Spain) and orbital (precessional) forcing for evaporite cyclicity. Sediment. Geol. 140, 43-60.

Kusznir, N.J., Kovkhuto, A., Stephenson, R.A., 1996. Syn-rift evolution of the Pripyat Trough: constraints from structural and stratigraphic modelling. Tectonophysics 268 , 221-236.

Leeder, M.R., 1991. Denudation, vertical crustal movements and sedimentary basin infill. Geol. Rundsch. 80, 441-458.

Leeder, M.R., Seger, M.J., Stark, C.P., 1991. Sedimentation and tectonic geomorphology adjacent to major active and inactive normal faults, southern Greece. J. Geol. Soc., London 148, 331-343.

Leever, K.A., Matenco, L., Bertotti, G., Cloetingh, S., Drijkoningen, G.G., 2006. Late orogenic vertical movements in the Carpathian Bend Zone - seismic constraints on the transition zone from Orogen to Foredeep. Basin Res. 18, 521-545.

Leppard, C.W., Gawthorpe, R.L., 2006. Sedimentology of rift climax deep water systems; lower Rudeis formation, Hammam faraun fault block, Suez rift. Egypt. Sediment. Geol. 191, 67-87. 
Manatschal, G., Lavier, L., Chenin, P., 2015. The role of inheritance in structuring hyperextended rift systems: some considerations based on observations and numerical modeling. Gondwana Res. 27, 140-164.

Mann, P., Hempton, M.R., Bradley, D.C., Burke, K., 1983. Development of pull-apart basins. J. Geol. 91, 529-554.

Mansor, M.Y., Rahman, A.H.A., Menier, D., Pubellier, M., 2014. Structural evolution of Malay Basin, its link to Sunda Block tectonics. Mar. Petrol. Geol. 58 (Part B), 736-748.

Martins-Neto, M.A., Catuneanu, O., 2010. Rift sequence stratigraphy. Mar. Petrol. Geol. $27,247-253$.

Matenco, L., Andriessen, P., 2013. Quantifying the mass transfer from mountain ranges to deposition in sedimentary basins: source to sink studies in the Danube Basin-black Sea system. Global Planet. Change 103, 1-18.

Matenco, L., Krézsek, C., Merten, S., Schmid, S., Cloetingh, S., Andriessen, P., 2010. Characteristics of collisional orogens with low topographic build-up: an example from the Carpathians. Terra Nova 22, 155-165.

Matenco, L., Munteanu, I., ter Borgh, M., Stanica, A., Tilita, M., Lericolais, G., Dinu, C., Oaie, G., 2016. The interplay between tectonics, sediment dynamics and gateways evolution in the Danube system from the Pannonian Basin to the western Black Sea. Sci. Total Environ. 543 (Part A), 807-827.

Matenco, L., Radivojević, D., 2012. On the formation and evolution of the Pannonian Basin: constraints derived from the structure of the junction area between the Carpathians and Dinarides. Tectonics 31https://doi.org/10.1029/2012tc003206. TC6007.

May, D.J., Walker, N.W., 1989. Late Cretaceous juxtaposition of metamorphic terranes in the southeastern San Gabriel Mountains, California. GSA Bull. 101, 1246-1267.

McKenzie, D., 1978. Some remarks on the development of sedimentary basins. Earth Planet. Sci. Lett. 40, 25-32.

McLaughlin, R.J., Nilsen, T.H., 2006. Neogene non-marine sedimentation and tectonics in small pull-apart basins of the San Andreas fault system, Sonoma County, California. Sedimentology 29, 865-876.

Meredith, D.J., Egan, S.S., 2002. The geological and geodynamic evolution of the eastern Black Sea basin: insights from 2-D and 3-D tectonic modelling. Tectonophysics 350, 157-179.

Milliman, J.D., Farnsworth, K.L., 2011. River Discharge to the Coastal Ocean: A Global Synthesis. Cambridge University Press, Cambridge 384 pp.

Mitchum Jr, R.M., Vail, P.R., Thompson III, S., 1977. Seismic stratigraphy and global changes of Sea level, part 2: the depositional sequence as a basic unit for stratigraphic analysis, seismic stratigraphy - applications to hydrocarbon exploration. In: In: Payton, C.E. (Ed.), American Association of Petroleum Geologists 26. pp. 33-45.

Morley, C.K., 1996. Models for relative motion of crustal blocks within the Carpathian region, based on restorations of the outer Carpathian thrust sheets. Tectonics 15, 885-904.

Morley, C.K., 2014. The widespread occurrence of low-angle normal faults in a rift setting: review of examples from Thailand, and implications for their origin and evolution. Earth-Sci. Rev. 133, 18-42.

Morley, C.K., Westaway, R., 2006. Subsidence in the super-deep Pattani and Malay basins of Southeast Asia: a coupled model incorporating lower-crustal flow in response to post-rift sediment loading. Basin Res. 18, 51-84.

Mosar, J., Eide, E.A., Osmundsen, P.T., Sommaruga, A., Torsvik, T.H., 2002. Greenland Norway separation: a geodynamic model for the North Atlantic. Nor. J. Geol. 82, $181-298$.

Munteanu, I., Matenco, L., Dinu, C., Cloetingh, S., 2012. Effects of large sea-level variations in connected basins: the Dacian-black Sea system of the Eastern Paratethys. Basin Res. 24, 583-597.

Naliboff, J.B., Buiter, S.J.H., Péron-Pinvidic, G., Osmundsen, P.T., Tetreault, J., 2017. Complex fault interaction controls continental rifting. Nat. Commun. 8, 1179. https://doi.org/10.1038/s41467-017-00904-x.

Naylor, M., Sinclair, H.D., 2008. Pro- vs. retro-foreland basins. Basin Res. 20, 285-303.

Neal, J.E., Abreu, V., Bohacs, K.M., Feldman, H.R., Pederson, K.H., 2016. Accommodation succession $(\delta \mathrm{A} / \delta \mathrm{S})$ sequence stratigraphy: observational method, utility and insights into sequence boundary formation. J. Geol. Soc. 173, 803-816.

Nijman, W., 1998. Cyclicity and basin axis shift in a piggyback basin: towards modelling of the Eocene Tremp-Ager Basin, South Pyrenees, Spain. In: In: Mascle, A., Puigdefàbregas, C., Luterbacher, H.P., Fernandez, M. (Eds.), Cenozoic Foreland Basins of Western Europe, vol. 134. Geological Society of London Special Publication, London, pp. 135-162.

Nixon, C.W., McNeill, L.C., Bull, J.M., Bell, R.E., Gawthorpe, R.L., Henstock, T.J., Christodoulou, D., Ford, M., Taylor, B, Sakellariou, D, Ferentinos, G., Papatheodorou, G., Leeder, M.R., Collier, R.E.L.I., Goodliffe, A.M., Sachpazi, M., Kranis, H., 2016. Rapid spatiotemporal variations in rift structure during development of the Corinth Rift, central Greece. Tectonics 35, 1225-1248.

Noda, A., 2016. Forearc basins: types, geometries, and relationships to subduction zone dynamics. Geol. Soc. Am. Bull. 128, 879-895.

Nottvedt, A., Gabrielsen, R.H., Steel, R.J., 1995. Tectonostratigraphy and sedimentary architecture of rift basins, with reference to the northern North Sea. Mar. Petrol. Geol. 12, 881-901.

Nourse, J.A., 2002. Middle Miocene reconstruction of the central and eastern San Gabriel Mountains, southern California, with implications for evolution of the San Gabriel fault and Los Angeles basin. In: In: Barth, A. (Ed.), Contributions to Crustal Evolution of the Southwestern United States, vol. 365. Geol. Soc. America Spec. Paper, pp. $1-40$.

Okay, A.I., Kaşlilar-Özcan, A., İmren, C., Boztepe-Güney, A., Demirbağ, E., Kuşçu, İ, 2000. Active faults and evolving strike-slip basins in the Marmara Sea, northwest Turkey: a multichannel seismic reflection study. Tectonophysics 321, 189-218.

Oncken, O., Chong, G., Franz, G., Giese, P., Götze, H.-J., Ramos, V.A., Strecker, M.R.,
Wigger, P., 2006. The Andes: Anctive Subcudtion Orogeny. Frontiers in Earth Sciences, XXII. Springer-Verlag, Berlin Heidelberg 569 pp.

Oszczypko, N., 2006. Late Jurassic-Miocene evolution of the Outer Carpathian fold-andthrust belt and its foredeep basin (Western Carpathians, Poland). Geol. Q. 50, 169-194.

Partington, M.A., Mitchener, B.C., Milton, N.J., Fraser, A.J., 1993. Genetic sequence stratigraphy for the North Sea Late Jurassic and early cretaceous: distribution and prediction of Kimmeridgian-late Ryazanian reservoirs in the North Sea and adjacent areas. In: Geological Society. London, Petroleum Geology Conference series 4. pp. 347-370.

Pereira, R., Alves, T.M., 2012. Tectono-stratigraphic signature of multiphased rifting on divergent margins (deep-offshore southwest Iberia, North Atlantic). Tectonics $31 \mathrm{https} / /$ doi.org/10.1029/2011tc003001. TC4001.

Platt, J.P., Behr, W.M., Johanesen, K., Williams, J.R., 2013. The betic-rif arc and its orogenic hinterland: a review. Ann. Rev. Earth Planet. Sci. 41, 313-357.

Pomar, L., Haq, B.U., 2016. Decoding depositional sequences in carbonate systems: concepts vs experience. Global Planet. Change 146, 190-225.

Posamentier, H.W., Allen, G.P., 1999. Siliciclastic sequence stratigraphy: concepts and applications. SEPM Concepts Sedimentol. Paleontol. 7210 pp.

Postma, G., Kleverlaan, K., 2018. Supercritical flows and their control on the architecture and facies of small-radius sand-rich fan lobes. Sediment. Geol. 364, 53-70.

Prosser, S., 1993. Rift related depositional system and their seismic expression. In: In: Williams, G.D., Dobb, A. (Eds.), Tectonics and Seismic Sequence Stratigraphy, vol. 71. Geol. Soc. London, Spec. Publ., pp. 35-66.

Pubellier, M., Morley, C.K., 2014. The basins of Sundaland (SE Asia): evolution and boundary conditions. Mar. Petrol. Geol 58 (Part B), 555-578.

Răbăgia, T., Matenco, L., 1999. Tertiary tectonic and sedimentological evolution of the South Carpathians foredeep: tectonic versus eustatic control. Mar. Petrol. Geol 16/17, 719-740.

Răbăgia, T., Matenco, L., Cloetingh, S., 2011. The interplay between eustacy, tectonics and surface processes during the growth of a fault-related structure as derived from sequence stratigraphy: the Govora-Ocnele Mari antiform, South Carpathians. Tectonophysics 502, 196-220.

Ratschbacher, L., Linzer, H.G., Moser, F., Strusievicz, R.O., Bedelean, H., Har, N., Mogos, P.A., 1993. Cretaceous to Miocene thrusting and wrenching along the central South Carpathians due to a corner effect during collision and orocline formation. Tectonics $12,855-873$.

Ravnas, R., Steel, R.J., 1998. Architecture of marine rift-basin successions. Bull. 82, $110-146$.

Ridd, M.F., 2013. A Middle Permian-middle Triassic accretionary complex and a Late Triassic foredeep basin: forerunners of an Indosinian (Late Triassic) thrust complex in the Thailand-malaysia border area. J. Asian Earth Sci. 76, 99-114.

Roca, X., Nadon, G.C., 2007. Tectonic control on the sequence stratigraphy of Nonmarine Retroarc Foreland Basin fills: insights from the upper Jurassic of Central Utah, U.S.A. J. Sediment. Res. 77, 239-255.

Rögl, F., 1999. Mediteranean and paratethys. Facts and hypotheses of an oligocene to miocene paleogeography. Geol. Carpath. 50, 339-349.

Roure, F., 2008. Foreland and Hinterland basins: what controls their evolution? Swiss J. Geosci. 101, 5-29.

Royden, L., Karner, G.D., 1984. Flexure of lithosphere beneath Apennine and Carpatian foredeep basins: evidence for an insufficient topografic load. AAPG Bull. 68, 704-712.

Sant, K., Palcu, D.V., Mandic, O., Krijgsman, W., 2017. Changing seas in the early-middle miocene of central Europe: a Mediterranean approach to paratethyan stratigraphy. Terra Nova 29, 273-281.

Santra, M., Steel, R.J., Olariu, C., Sweet, M.L., 2013. Stages of sedimentary prism development on a convergent margin - Eocene Tyee Forearc Basin, Coast Range, Oregon, USA. Global Planet. Change 103, 207-231.

Sato, H., Ishiyama, T., Matenco, L., Nader, F.H., 2017. Evolution of fore-arc and back-arc sedimentary basins with focus on the Japan subduction system and its analogues. Tectonophysics $710,1-5$.

Schlager, W., 1993. Accommodation and supply - a dual control on stratigraphic sequences. Sediment. Geol. 86, 111-136.

Schmid, S., Bernoulli, D., Fügenschuh, B., Matenco, L., Schefer, S., Schuster, R., Tischler, M., Ustaszewski, K., 2008. The Alpine-Carpathian-Dinaridic orogenic system: correlation and evolution of tectonic units. Swiss J. Geosci. 101, 139-183.

Scholz, C.A., Johnson, T.C., McGill, J.W., 1993. Deltaic sedimentation in a rift valley lake: new seismic reflection data from Lake Malawi (Nyasa), East Africa. Geology 21, 395-398.

Shanley, K.W., McCabe, P.J., 1991. Predicting facies architecture through sequence stratigraphy - an example from the Kaiparowits Plateau, Utah. Geology 19, 742-745.

Sinclair, H.D., 1993. High resolution stratigraphy and facies differentiation of the shallow marine Annot Sandstones, South-east France. Sedimentology 40, 955-978.

Sinclair, H.D., 1997. Flysch to Molasse transition in peripheral foreland basins: the role of the passive margin versus slab breakoff. Geology 25, 1123-1126.

Slatt, R.M., Stone, C.G., Weimer, P., 2000. Characterization of slope and Basin facies tracts, Jackfork Group, Arkansas, with Applications WR Deepwater (Turbidite) Reservoir Management. In: In: Weimer, P. (Ed.), Deep-Water Reservoirs of the World 20. SEPM Society for Sedimentary Geology, pp. 23-57.

Steckler, M.S., Watts, A.B., 1978. Subsidence of the Atlantic-type continental margin off New York. Earth Planet. Sci. Lett. 41, 1-13.

Stein, S., Stein, C.A., Elling, R., Kley, J., Keller, G.R., Wysession, M., Rooney, T., Frederiksen, A., Moucha, R., 2018. Insights from North America's failed Midcontinent Rift into the evolution of continental rifts and passive continental margins. Tectonophysics 744, 403-421.

Stephenson, R., 1989. Beyond first-order thermal subsidence models for sedimentary 
basins? In: Cross, T.A. (Ed.), Quantitative Dynamic Stratigraphy. Prentice-Hall, New Jersey, pp. 113-125.

Stockmal, G.S., Beaumont, C., Boutilier, R., 1986. Geodynamic models of convergent margin tectonics: transition from rifted margin to overthrust belt and consequences for foreland-basin development. AAPG Bull. 70, 181-190.

Strachan, L.J., Rarity, F., Gawthorpe, R.L., Wilson, P., Sharp, I., Hodgetts, D., 2013. Submarine slope processes in rift-margin basins, Miocene Suez Rift, Egypt. GSA Bulletin 125, 109-127.

Suades, E., Crespo-Blanc, A., 2013. Gravitational dismantling of the Miocene mountain front of the Gibraltar Arc system deduced from the analysis of an olistostromic complex (western Betics). Geol. Acta 11, 215-229.

Suades Sala, E., 2015. Intergrated Onshore-offshore Study in the Northwestern Margin of the Alboran Basin. University of Granada, Granada 344 pp.

Tărăpoancă, M., Andriessen, P., Broto, K., Chérel, L., Ellouz-Zimmermann, N., Faure, J.L., Jardin, A., Naville, C., Roure, F., 2010. Forward kinematic modelling of a regional transect in the Northern Emirates using geological and apatite fission track age constraints on paleo-burial history. Arab. J. Geosci. 3 395-411-411.

ter Borgh, M., 2013. Connections Between Sedimentary Basins During Continental Collision: How Tectonic, Surface and Sedimentary Processes Shaped the Paratethys. PhD Thesis. Utrecht University, Utrecht 212 pp.

ter Borgh, M., Radivojević, D., Matenco, L., 2015. Constraining forcing factors and relative sea-level fluctuations in semi-enclosed basins: the Late Neogene demise of Lake Pannon. Basin Res. 27, 681-695.

Thiede, R.C., Ehlers, T.A., 2013. Large spatial and temporal variations in Himalayan denudation. Earth Planet. Sci. Lett. 371-372, 278-293.

Tiliţă, M., Matenco, L., Dinu, C., Ionescu, L., Cloetingh, S., 2013. Understanding the kinematic evolution and genesis of a back-arc continental "sag" basin: the Neogene evolution of the Transylvanian Basin. Tectonophysics 602, 237-258.

Tiliţă, M., Scheck-Wenderoth, M., Matenco, L., Cloetingh, S., 2015. Modelling the coupling between salt kinematics and subsidence evolution: inferences for the Miocene evolution of the Transylvanian Basin. Tectonophysics 658, 169-185.

Tirel, Cl, Brun, J.-P., Burov, E., 2008. Dynamics and structural development of metamorphic core complexes. J. Geophys. Res. 113.

Turcotte, D.L., Ahern, J.L., 1977. On the thermal and subsidence history of sedimentary basins. J. Geophys. Res. 82, 3762-3766.

Uyeda, S., Kanamori, H., 1979. Back-arc opening and the mode of subduction. J. Geophys. Res. 84, 1049-1061.

Vail, P.R., Mitchum Jr, R.M., Thompson III, S., 1977a. In: In: Payton, C.E. (Ed.), Seismic Stratigraphy and Global Changes of Sea Level, Part 4: Global Cycles of Relative Changes of Sea Level, Seismic Stratigraphy - Applications to Hydrocarbon Exploration, vol. 26. AAPG Memoir, pp. 98-122.

Vail, P.R., Mitchum, R.M., Thompson, S., 1977b. Seismic stratigraphy and global changes of Sea level, part 3: relative changes of Sea level from coastal onlap. In: In: Pyton, E.C. (Ed.), Seismic Stratigraphy-Application to Hydrocarbon Exploration 26. AAPG Memoir, pp. 83-97.

van Hinsbergen, D.J.J., Vissers, R.L.M., Spakman, W., 2014. Origin and consequences of western Mediterranean subduction, rollback, and slab segmentation. Tectonics 33, 393-419.

van Wagoner, J.C., Mitchum, R.M., Campion, K.M., Rahmanian, V.D., 1990. Siliciclastic sequence stratigraphy in well logs, cores, and outcrops. Am. Ass. Petrol. Geol. Expl. Ser. 7, 1-55.

van Wijk, J., Axen, G., Abera, R., 2017. Initiation, evolution and extinction of pull-apart basins: implications for opening of the Gulf of California. Tectonophysics 719-720, $37-50$.

van Wijk, J., van Hunen, J., Goes, S., 2008. Small-scale convection during continental rifting: evidence from the Rio Grande rift. Geology 36, 575-578.

van Wijk, J.W., Cloetingh, S.A.P.L., 2002. Basin migration caused by slow lithospheric extension. Earth Planet. Sci. Lett. 198, 275-288.

Vergés, J., Fernàndez, M., 2012. Tethys-Atlantic interaction along the Iberia-Africa plate boundary: the Betic-Rif orogenic system. Tectonophysics 579, 144-172.

Vilasi, N., Malandain, J., Barrier, L., Callot, J.-P., Amrouch, K., Guilhaumou, N., Lacombe, O., Muska, K., Roure, F., Swennen, R., 2009. From outcrop and petrographic studies to basin-scale fluid flow modelling: the use of the Albanian natural laboratory for carbonate reservoir characterisation. Tectonophysics 474, 367-392.

Vissers, R.L.M., 2012. Extension in a convergent tectonic setting: a lithospheric view on the Alboran system of SW Europe. Geol. Belg. 15, 53-72.

von Hagke, C., Oncken, O., Ortner, H., Cederbom, C.E., Aichholzer, S., 2014. Late Miocene to present deformation and erosion of the Central Alps - evidence for steady state mountain building from Thermokinematic data. Tectonophysics 632, 250-260.

Wagreich, M., 1995. Subduction tectonic erosion and Late Cretaceous subsidence along the northern Austroalpine margin (Eastern Alps, Austria). Tectonophysics 242, 63-78.

Waschbusch, P.J., Royden, L.H., 1992. Episodicity in foredeep basins. Geology 20, 915-918.

Watts, A.B., 1989. Lithospheric flexure due to prograding sediment loads: implications for the origin of offlap/onlap patterns in sedimentary basins. Basin Res. 2, 133-144.

Watts, A.B., 1992. The effective elastic thickness of the lithosphere and the evolution of foreland basins. Basin Res. 4, 169-178.

Watts, A.B., Piatt, J.P., Buhl, P., 2007. Tectonic evolution of the Alboran Sea basin. Basin Res. 5, 153-177.

Wernicke, B., 1985. Uniform-sense normal simple shear of the continental lithosphere. Can. J. Earth Sci. 22, 108-125.

Willett, S.D., Brandon, M.T., 2002. On steady states in mountain belts. Geology 30, $175-178$.

Willett, S.D., Schlunegger, F., Picotti, V., 2006. Messinian climate change and erosional destruction of the central European Alps. Geology 34, 613-616.

Williams, G.D., Powell, C.M., Cooper, M.A., 1989. Geometry and kinematics of inversion tectonics. In: In: Cooper, M.A., Williams, G.D. (Eds.), Inversion Tectonics 44. Geol. Soc. London Spec. Publ., London, pp. 3-15.

Xie, X., Heller, P.L., 2009. Plate tectonics and basin subsidence history. GSA Bull. 121, 55-64.

Yamasaki, T., Stephenson, R., 2009. Change in tectonic force inferred from basin subsidence: implications for the dynamical aspects of back-arc rifting in the western Mediterranean. Earth Planet. Sci. Lett. 277, 174-183.

Yeats, R.S., 2004. Tectonics of the San Gabriel Basin and surroundings, southern California. GSA Bull. 116, 1158-1182.

Ziegler, P.A., Bertotti, G., Cloetingh, S., 2002. Dynamic processes controlling foreland development - the role of mechanical (de)coupling of orogenic wedges and forelands. In: In: Bertotti, G., Schulmann, K., Cloetingh, C. (Eds.), Continental Collision and the Tectono-Sedimentary Evolution of Forelands 1. Europ. Geophys. Soc. Stephan Mueller Special Publication Series, pp. 17-56.

Ziegler, P.A., Cloetingh, S., 2004. Dynamic processes controlling evolution of rifted basins. Earth-Sci. Rev. 64, 1-50.

Ziegler, P.A., Cloetingh, S., van Wees, J.-D., 1995. Dynamics of intra-plate compressional deformation: the Alpine foreland and other examples. Tectonophysics 252, 7-22.

Zweigel, J., Aigner, T., Luterbacher, H., 1998. Eustatic versus tectonic controls on Alpine foreland basin fill: sequence stratigraphy and subsidence analysis in the SE German Molasse. Geol. Soc. Lond. Spec. Publ. 134, 299. 